Hydrol. Earth Syst. Sci., 12, 863-885, 2008

www.hydrol-earth-syst-sci.net/12/863/2008/

(C) Author(s) 2008. This work is distributed under

the Creative Commons Attribution 3.0 License.

\title{
Global-scale modeling of groundwater recharge
}

\author{
P. Döll and K. Fiedler \\ Institute of Physical Geography, University of Frankfurt, Frankfurt am Main, Germany \\ Received: 24 October 2007 - Published in Hydrol. Earth Syst. Sci. Discuss.: 15 November 2007 \\ Revised: 10 March 2008 - Accepted: 23 March 2008 - Published: 29 May 2008
}

\begin{abstract}
Long-term average groundwater recharge, which is equivalent to renewable groundwater resources, is the major limiting factor for the sustainable use of groundwater. Compared to surface water resources, groundwater resources are more protected from pollution, and their use is less restricted by seasonal and inter-annual flow variations. To support water management in a globalized world, it is necessary to estimate groundwater recharge at the global scale. Here, we present a best estimate of global-scale long-term average diffuse groundwater recharge (i.e. renewable groundwater resources) that has been calculated by the most recent version of the WaterGAP Global Hydrology Model WGHM (spatial resolution of $0.5^{\circ}$ by $0.5^{\circ}$, daily time steps). The estimate was obtained using two state-of-the-art global data sets of gridded observed precipitation that we corrected for measurement errors, which also allowed to quantify the uncertainty due to these equally uncertain data sets. The standard WGHM groundwater recharge algorithm was modified for semi-arid and arid regions, based on independent estimates of diffuse groundwater recharge, which lead to an unbiased estimation of groundwater recharge in these regions. WGHM was tuned against observed long-term average river discharge at 1235 gauging stations by adjusting, individually for each basin, the partitioning of precipitation into evapotranspiration and total runoff. We estimate that global groundwater recharge was $12666 \mathrm{~km}^{3} / \mathrm{yr}$ for the climate normal $1961-1990$, i.e. $32 \%$ of total renewable water resources. In semi-arid and arid regions, mountainous regions, permafrost regions and in the Asian Monsoon region, groundwater recharge accounts for a lower fraction of total runoff, which makes these regions particularly vulnerable to seasonal and inter-annual precipitation variability and water pollution. Average per-capita renewable ground-
\end{abstract}

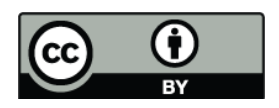

Correspondence to: P. Döll (p.doell@em.uni-frankfurt.de) water resources of countries vary between $8 \mathrm{~m}^{3} /($ capita yr) for Egypt to more than 1 million $\mathrm{m}^{3}$ (capita yr) for the Falkland Islands, the global average in the year 2000 being $2091 \mathrm{~m}^{3} /$ (capita yr). Regarding the uncertainty of estimated groundwater resources due to the two precipitation data sets, deviation from the mean is $1.1 \%$ for the global value, and less than $1 \%$ for 50 out of the 165 countries considered, between 1 and $5 \%$ for 62 , between 5 and $20 \%$ for 43 and between 20 and $80 \%$ for 10 countries. Deviations at the grid scale can be much larger, ranging between 0 and $186 \mathrm{~mm} / \mathrm{yr}$.

\section{Introduction}

Groundwater recharge is the major limiting factor for the sustainable use of groundwater because the maximum amount of groundwater that may be withdrawn from an aquifer without irreversibly depleting it, under current climatic conditions, is approximately equal to long-term (e.g. 30 years) average groundwater recharge. Therefore, long-term average groundwater recharge is equivalent to renewable groundwater resources. Depletion of non-renewable ("fossil") groundwater resources by human water withdrawals can be quantified by comparing withdrawal rates to groundwater recharge. Groundwater recharge either occurs, locally, from surface water bodies or, in diffuse form, from precipitation via the unsaturated soil zone. Long-term average diffuse groundwater recharge is the part of precipitation that does not evapotranspirate and does not run off to a surface water body on the soil surface or within the unsaturated zone. Only diffuse groundwater recharge is taken into account in this paper, as groundwater recharge from surface water bodies cannot be estimated at the macro-scale. In semi-arid and arid regions, outside the mountainous headwater regions, neglecting groundwater recharge from surface-water bodies may lead to a significant underestimation of total renewable

Published by Copernicus Publications on behalf of the European Geosciences Union. 
groundwater resources. Hereafter, the term groundwater recharge refers only to diffuse recharge.

In most regions of the world, a large part of groundwater recharge is transported to surface waters, and is thus included in estimates of surface water resources derived from river discharge measurements (groundwater close to the coast may discharge directly into the ocean, and in semi-arid and arid regions, a part of the groundwater recharge evapotranspirates before discharging into a river). Nevertheless, it is useful to quantify groundwater resources separately. First, they are much better protected from pollution than surface water resources. Second, the use of groundwater resources is much less restricted by seasonal or inter-annual flow variations (e.g. drought periods) than the use of surface water. To support water management in a globalized world, it is therefore necessary to estimate, in a spatially resolved way, groundwater recharge and thus renewable groundwater resources at the global scale.

Different from surface water resources, groundwater recharge cannot be easily measured. While surface water resources are concentrated in the river channels of a drainage basin and thus can be determined by measuring river discharge, groundwater recharge, like precipitation, is distributed spatially, and a very large number of measurements would be necessary to obtain a good estimate for a sizeable area. Besides, groundwater recharge, unlike precipitation, cannot be directly measured as a volume flow but must be determined by a variety of indirect methods where either the unsaturated zone or the groundwater is analyzed (Lerner, 1990; Simmers, 1997; Scanlon et al., 2002). In humid regions, groundwater recharge is generally estimated from the baseflow component of measured river discharge. However, it is well known that computed baseflow values strongly depend on the method that has been applied for baseflow analysis such that baseflow indices (baseflow as a fraction of total flow) can vary by a factor of 2 (Tallaksen, 1995; Bullock et al., 1997; Neumann, 2005). Besides, baseflow analysis does not lead to meaningful results if gauging stations are downstream of large reservoirs, lakes or wetlands (L'vovich, 1979). Baseflow analysis in semi-arid and arid regions is likely to lead to an underestimation of groundwater recharge, as part of the recharge evapotranspirates before reaching (larger) rivers (Margat, 1990:33). Finally, it must be kept in mind that the concept of renewable groundwater resources and its relation to groundwater recharge and baseflow is scale-dependent as a part of the groundwater recharge might reappear as surface water after a very short travel distance.

The first global-scale study of groundwater recharge was accomplished by L'vovich (1979), whose global map of groundwater recharge was based on the estimation of the baseflow component of observed river discharge. A number of institutions have compiled global lists of country values of groundwater recharge (Margat, 1990; WRI, 2000; FAO, 2003, 2005). In the compilation of WRI (2000), many val- ues stem from Margat (1990) which again often used estimates of the global analysis of L'vovich (1979). The most recent estimates of groundwater recharge per country have been compiled by FAO (2005), and include mainly data collected for FAO country reports (150 countries) and data from national sources, but a few country values are still those of the global-scale analysis of L'vovich (1979). The country values of groundwater recharge have been obtained by very diverse methods mostly in the 70 s, 80 s and 90 s of the 20th century. WRI $(2005 \mathrm{a}, \mathrm{b})$, in their presentation of the FAO (2005) groundwater recharge values, warn that "all data should be considered order-of-magnitude estimates" and that "cross-country comparisons should therefore be made with caution". Comparing WRI (2000) and FAO (2005) estimates, for the 131 countries for which values exist in both data sets, 69 country values are the same, while 14 country values differ by more than $50 \%$.

After L'vovich (1979), no other global-scale analysis was performed until Döll et al. (2002) obtained the first modelbased estimates of groundwater recharge at the global scale. With a spatial resolution of $0.5^{\circ}$ geographical latitude by $0.5^{\circ}$ geographical longitude, diffuse groundwater recharge for the climate normal 1961-1990 was estimated with the global hydrological model WGHM (WaterGAP Global Hydrology Model, Döll et al., 2003; Alcamo et al., 2003). In that version of WGHM, long-term average total runoff, i.e. the sum of groundwater recharge and fast surface and subsurface flow, was tuned against observed river discharge at 724 stations world-wide by adjusting basin-specific parameters. Later, the WGHM groundwater recharge algorithm was improved for semi-arid and arid regions, and the model was used to estimate the impact of climate change on groundwater recharge (Döll and Flörke, 2005). The model was also applied to analyze the contribution of groundwater to largescale water storage variations as derived from gravity measurements of the GRACE satellite mission (Güntner et al., $2007 \mathrm{a}, \mathrm{b}$ ). The analysis showed a large spatial variability of groundwater storage dynamics, both in absolute values and as a fraction of total water storage. As expected, because of its longer residence times, groundwater can decrease the seasonal variation of total water storage, and it tends to have a larger contribution to total storage change for interannual than for seasonal storage dynamics. Besides, WGHM groundwater recharge estimates were included in the Hydrogeological Map of Africa of Seguin (2005).

The goal of this paper is to present the most recent estimates of groundwater recharge at the global scale as obtained with the new WGHM version $2.1 \mathrm{f}$ for the time period 1961-1990. This new model version differs from the former versions by, among other changes, an increased number of now 1,235 river discharge observation stations that are used to tune the model. These stations lead to an improved spatial representation of total runoff (Hunger and Döll, 2008), and thus probably groundwater recharge. Besides, two state-ofthe-art precipitation data sets are used as alternative model 


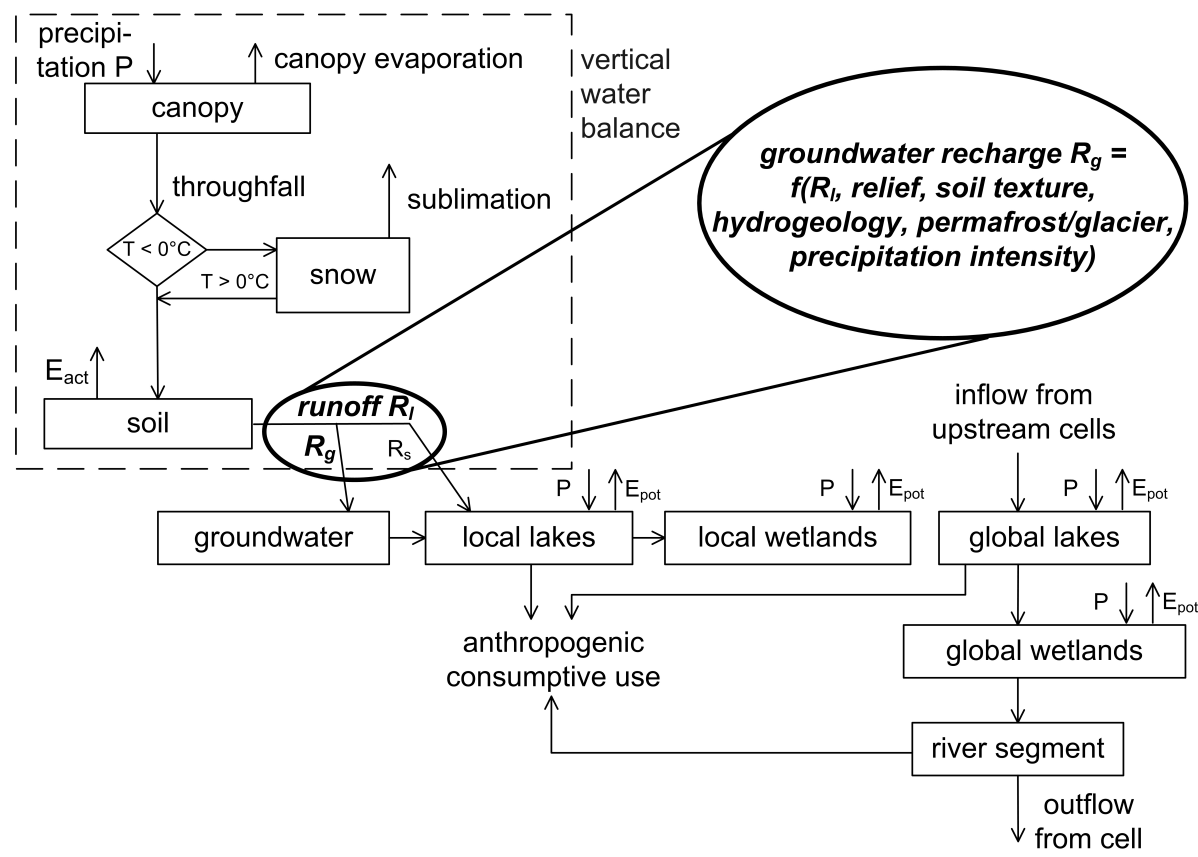

Fig. 1. Schematic representation of water flows and storages in each 0.5 degree grid cell as simulated by the global hydrological model WGHM, highlighting the computation of diffuse groundwater recharge. $E_{\text {pot }}$ : potential evapotranspiration, $E_{\text {act }}$ : actual evapotranspiration from soil.

inputs, in order to characterize the important uncertainty of estimated groundwater recharge that is due to uncertainty of global-scale precipitation estimates. Precipitation is the major driver of groundwater recharge; for areas with arid to humid climate in southwestern USA, Keese et al. (2005) found the mean annual precipitation explains $80 \%$ of the variation of groundwater recharge. WGHM groundwater recharge estimates will be included in the Global Map of Groundwater Resources developed in UNESCO's "World-wide Hydrogeological Mapping and Assessment Program" WHYMAP (http://www.whymap.org, final release summer 2008).

Other hydrological models as well as the land surface schemes of climate models also compute variables that could be considered as diffuse groundwater recharge. To our knowledge, however, these model outputs have not yet been analyzed and interpreted at the global scale. In the Second Global Soil Wetness Project, for example, where the output of 13 land surface models was compared, groundwater recharge was lumped with interflow (Dirmeyer et al., 2005).

In the next section, we present the WGHM approach of modeling groundwater recharge as well as the precipitation data sets. In Sect. 3, we show the computed global groundwater recharge and resources maps including a quantification of the error due to precipitation uncertainty and compare groundwater resources to total water resources. In Sect. 4, we discuss the quality of the results, while in Sect. 5, we draw some conclusions.

\section{Methods and data}

\subsection{Model description}

A detailed presentation of the WaterGAP Global Hydrology Model (WGHM), including process formulations, input data, model tuning, and validation is given by Döll et al. (2003). The newest model version WGHM 2.1f is presented by Hunger and Döll (2008). Here, a short model overview is provided, and the groundwater recharge algorithm is described in detail.

\subsubsection{WGHM overview}

The WaterGAP 2 model (Alcamo et al., 2003) includes both the global hydrological model WGHM and a number of water use models that compute consumptive and withdrawal water use for irrigation (Döll and Siebert, 2002), livestock, industry (Vassolo and Döll, 2006) and households. Therefore, in WGHM, river discharge reduction due to human water use can be taken into account by subtracting consumptive water use (water withdrawals minus return flows) from surface water bodies. It is assumed that total consumptive water use is taken from surface waters (Fig. 1) as there is currently no information, at the global scale, on the fraction of total water withdrawal that is abstracted from groundwater.

WHGM simulates the vertical water balance and lateral transport with a spatial resolution of $0.5^{\circ}$ by $0.5^{\circ}$, covering the global land area with the exception of Antarctica (66 896 


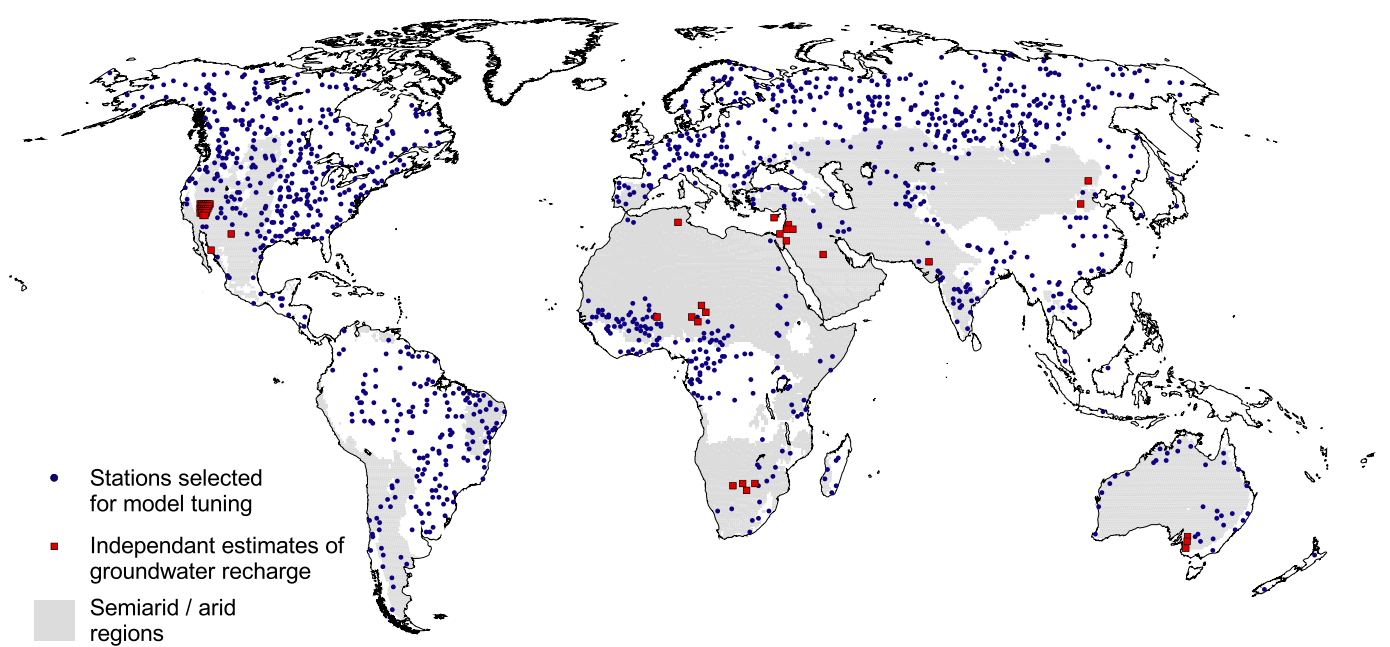

Fig. 2. Location of 1235 river discharge stations for basin-specific tuning, location of independent estimates of groundwater recharge, and semi-arid and arid areas where modified groundwater recharge algorithm was applied.

cells). Figure 1 shows the storages and fluxes that are simulated for each grid cell with a time step of 1 day. It is assumed that groundwater recharged within one cell leaves the groundwater store as baseflow within the same cell. Water flow between grid cells is assumed to occur only as river discharge, following a global drainage direction map (Döll and Lehner, 2002). Water flow from surface water bodies to groundwater is not taken into account. For each time step, the net runoff of each cell is computed as the balance of precipitation, evapotranspiration from canopy, soil and surface waters, and water storages changes within the cell.

WGHM is tuned, individually for 1235 large drainage basins, against observed long-term average river discharge (Fig. 2) by optimizing a parameter in the soil water balance algorithm, the so-called runoff coefficient, and, if necessary, by introducing correction factors (Hunger and Döll, 2008). By tuning, the difference between long-term average precipitation and evapotranspiration, i.e. total runoff, in each tuning basin (during the observation period) becomes equal to long-term average observed river discharge. Given the large uncertainties of both the climate input data (in particular precipitation) and the hydrological model, this type of tuning helps to obtain rather realistic water flows in the basins. However, in semi-arid and arid regions, tuning is likely to lead to an underestimation of runoff generation, as river discharge at a downstream location is likely to be less than the runoff generated in the basin, due to evapotranspiration of runoff and leakage from the river. The tuning basins cover almost half of the global land area (except Antarctica and Greenland). For the remaining river basins, the runoff coefficients are obtained by regionalizing the runoff coefficients of the tuning basins. This was done by a multiple regression analysis which relates the runoff coefficient for all the grid cells within the basin to the following basin characteristics: long-term average temperature, fraction of open water surfaces and length of non-perennial rivers (Döll et al., 2003). Outside the tuning basins, the correction factors are set to 1 .

\subsubsection{Groundwater recharge algorithm}

Daily groundwater recharge $R_{g}$ is computed as part of the vertical water balance of each grid cell (Fig. 1). In order to calculate $R_{g}$, total runoff from land $R_{l}$ is partitioned into fast surface and subsurface runoff $R_{s}$ and groundwater recharge $R_{g}$. Following a heuristic approach, this is done based on qualitative knowledge about the influence of the following characteristics on the partitioning of runoff: relief, soil texture, hydrogeology and the occurrence of permafrost and glaciers. With steeper slopes, finer soil textures and less permeable aquifers, groundwater recharge as a fraction of total runoff from land is expected to decrease, and permafrost and glaciers are assumed to prevent groundwater recharge. Besides, soils have a texture-related infiltration capacity, which, if exceeded in case of intense rainfalls, prevents groundwater recharge (causing surface runoff to occur); the finer the soil texture, the lower the infiltration capacity. Accordingly, $R_{g}$ is computed as

$$
\begin{array}{ll}
R_{g}=\min \left(R_{g \max }, f_{g} R_{l}\right) \text { with } f_{g}=f_{r} f_{t} f_{h} f_{p g} \\
R_{g \max }= & \begin{array}{l}
\text { soil texture-specific maximum groundwater } \\
\text { recharge (infiltration capacity) }[\mathrm{mm} / \mathrm{d}]
\end{array} \\
R_{l}= & \text { total runoff of land area of cell }[\mathrm{mm} / \mathrm{d}] \\
f_{g}= & \text { groundwater recharge factor }\left(0 \leq f_{g}<1\right) \\
f_{r}= & \text { relief-related factor }\left(0<f_{r}<1\right) \\
f_{t}= & \text { soil texture-related factor }\left(0 \leq f_{t} \leq 1\right) \\
f_{h}= & \text { hydrogeology-related factor }\left(0<f_{h}<1\right) \\
f_{p g}= & \text { permafrost/glacier-related factor }\left(0 \leq f_{p g} \leq 1\right)
\end{array}
$$


A number of other possible physio-geographic characteristics like land cover, precipitation, surface drainage density and depth to groundwater have not been included in the algorithm for various reasons. Haberlandt et al. (2001) found, in their study on baseflow indices BFI (baseflow as a ratio of total runoff from land) in the Elbe basin that the proportion of forest and arable land (i.e. land cover) in sub-basins of or below the size of $0.5^{\circ}$ grid cells only had a weak influence on BFI. Precipitation was not included as a predictor in Eq. (1) as 1) it is already included as an inflow to the model, and 2) two regional-scale regression analyses of BFI lead to conflictive results. In the Central European Elbe basin, where more rain falls in mountainous areas, there was a strong negative correlation between BFI and precipitation (Haberlandt et al., 2001). The opposite behavior was found in Southern Africa where more rain falls in the northern flat regions (Bullock et al., 1997). Depth to groundwater and surface drainage density, which were identified by Jankiewicz et al. (2005) as good predictors for estimating groundwater recharge in Germany at a spatial resolution $1 \mathrm{~km}$ by $1 \mathrm{~km}$ (in addition to total runoff, soil texture, slope, and land cover), are not available at the global scale at all or not at an appropriate resolution, respectively. Besides, in the regression analysis of Jankiewicz et al. (2005), the depth to groundwater was found to have the opposite effect in areas with high $(>200 \mathrm{~mm} / \mathrm{yr})$ vs. low total runoff.

Global-scale information on relief (G. Fischer, IIASA, personal communication, 1999), soil texture (FAO, 1995), hydrogeology (Canadian Geological Survey, 1995) and the occurrence of permafrost and glaciers (Brown et al., 1998; Hoelzle and Haeberli, 1999) was available at different spatial resolutions and is described in more detail in Appendix A. The cell-specific values of all four basic factors and of the texture specific maximum groundwater recharge in Eq. (1) were computed by first assigning values to the attributes of the global data sets (e.g. a $f_{t}$-value of 1 was assigned to coarse, a $f_{t}$-value of 0.7 to fine soil texture, Appendix A2). Then, the values were upscaled to $0.5^{\circ}$ by $0.5^{\circ}$. The specific values for the four factors $f_{r}, f_{t}, f_{h}$ and $f_{p g}$ are expert guesses that have been adjusted iteratively by comparing the resulting spatial distribution of groundwater recharge and base flow indices with the global map of L'vovich (1979) as well as regional maps for the Elbe basin (Haberlandt et al., 2001), Southern Africa (Bullock et al., 1997) and Southwestern Germany (B. Lehner, personal communication).

For semi-arid and arid conditions, modeling of runoff and groundwater recharge is generally found to be more difficult than for humid areas, mainly due to the small values of these variables. Besides, river discharge measurements are not as indicative of groundwater recharge as under humid conditions, where most of the groundwater recharge reaches a river. However, under semi-arid and arid conditions, it is possible to estimate long-term average groundwater recharge based on the analysis of chloride profiles in the soil and isotope measurements. Such estimates for 25 locations which

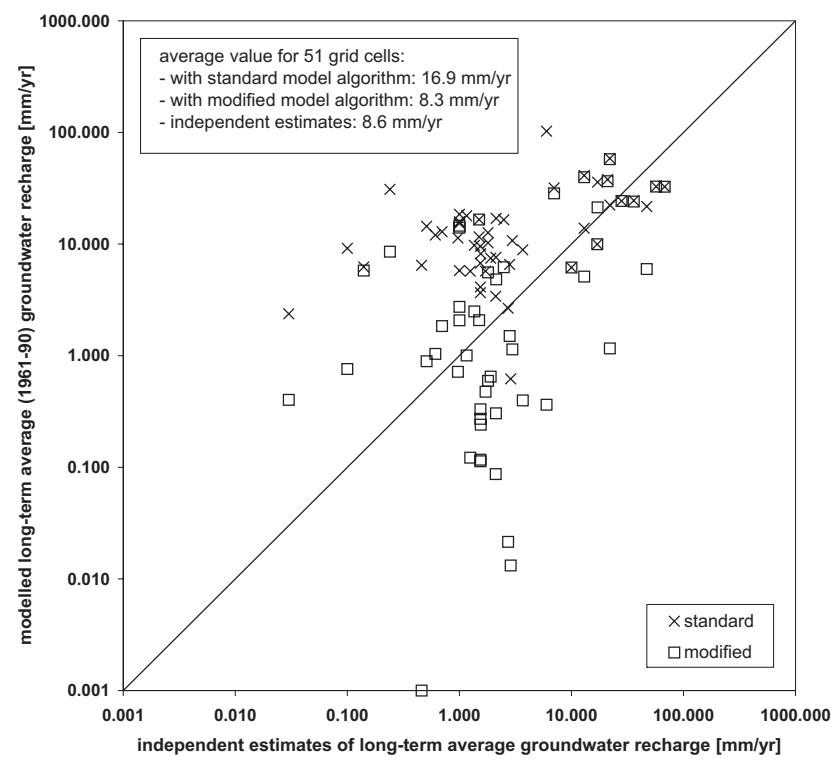

Fig. 3. Improved modeling of groundwater recharge due to modified groundwater recharge algorithm for semi-arid regions: comparison of independent estimates of long-term average groundwater recharge for 51 grid cells in semi-arid regions with modeled values as computed with the standard and the modified algorithm (using GPCC precipitation).

are representative not only for the profile location but a larger area of $25 \mathrm{~km}$ by $25 \mathrm{~km}$ were compiled by Mike Edmunds (University of Oxford, personal communication, 2003) and were used to test the performance of Eq. (1), and to modify the groundwater recharge algorithm of WGHM for semi-arid and arid grid cells (Fig. 2). In most cases, the data are representative for the $50-100$ year period before the measurements. The observed data are from Northern and Southern Africa, the Near East, Asia and Australia (Fig. 2). In addition, groundwater recharge as computed by a meso-scale hydrological model of the Death Valley region in southwestern USA (Hevesi et al., 2003) was taken into account. The meso-scale model results, which are representative for the time period 1950-1999, were upscaled to derive estimates for the $260.5^{\circ}$ grid cells of WGHM which cover the region (Fig. 2).

We found that WGHM, with Eq. (1), significantly overestimates groundwater recharge at the semi-arid and arid observation sites, in particular groundwater recharge below $20 \mathrm{~mm} / \mathrm{a}$ (Fig. 3). This could be caused by either an overestimation of total runoff (likely in semi-arid and arid basins without discharge measurements) or an overestimation of groundwater recharge as a fraction of total runoff. For the Death Valley region, WGHM overestimates total runoff by about an order of $10(50 \mathrm{~mm} / \mathrm{yr}$ instead of $5 \mathrm{~mm} / \mathrm{yr})$, which can only partially be explained by an overestimation of precipitation. Where the groundwater recharge fraction is overestimated, the preferred tuning method would be to modify 
the groundwater recharge factors in Eq. (1). However, an analysis of the 51 grid cells with independent estimates showed that an adjustment of the recharge factors cannot lead to the necessary decrease in groundwater recharge, as most cells that require a strong reduction of computed groundwater recharge have low relief, coarse soil and young sedimentary aquifers, which means that they should have relatively large groundwater recharge fractions. We concluded that the WGHM conceptual model of groundwater recharge is less appropriate for semi-arid than for humid regions, as, compared to humid regions, semi-arid and arid regions share the following characteristics:

- A larger variability of precipitation with more heavy rainfalls

- Surface crusting in areas of weak vegetation cover, which strongly reduces infiltration into the soil

- Reduced infiltration of heavy rain into dry soil due to pore air which has to be released first to allow the infiltration. Additionally, the moistening of dry soil surfaces is reduced due to hydrophobic behavior of dried organic materials.

- More infiltration and thus groundwater recharge in soils with fine texture as compared to soils with coarse texture. In very dry conditions, the low unsaturated hydraulic conductivity of sands, for example, leads to a lower infiltration capacity for sand as compared to loam, which, at the same matric potential, has a much higher water content and unsaturated hydraulic conductivity.

- In some regions, groundwater recharge only occurs via fissures in crystalline rock which allow the rainwater to leave the zone of capillary rise faster than in the case of sand. Rainwater that remains in the capillary zone evaporates due to high temperatures and radiation in semiarid regions. In humid regions, groundwater recharge in fissured crystalline rocks is expected to be lower than in sandy sediments.

Altogether, in semi-arid regions groundwater recharge appears to be confined to periods of exceptionally heavy rainfall (Vogel and Van Urk, 1975), in particular if soil texture is coarse (Small, 2005). Therefore, the computation of groundwater recharge in semi-arid and arid grid cells, with a medium to coarse soil texture, was modified such that groundwater recharge as modeled with Eq. (1) occurs only if the daily precipitation is larger than $10 \mathrm{~mm} / \mathrm{d}$. Following the definition of UNEP and the United Nations Convention to Combat Desertification (UNEP, 1992), semi-arid/arid grid cells are those with long-term average (1961-1990) precipitation less or equal to half the potential evapotranspiration. The grid cells which obey this rule but are north of $60^{\circ} \mathrm{N}$ were not defined as "semi-arid". This modification of the groundwater recharge algorithm resulted in an unbiased estimation of groundwater recharge (Fig. 3) and also improved the correlation between observed and computed values (from $R^{2}=0.14$ to $R^{2}=0.37$ )

\subsection{Precipitation data sets}

WGHM is driven by time series of $0.5^{\circ}$ gridded observed monthly climate variables between 1901 and 2002, including precipitation, air temperature, cloudiness and number of wet days (CRU TS 2.0 data set, Mitchell and Jones, 2005). Daily observed climate data are not available globally at the $0.5^{\circ}$ resolution for a period of 30 years, i.e. long enough to average out temporal climate variability. Daily values for long periods of time can only be obtained from re-analysis, i.e. computations with general circulation models, but the computed precipitation fields do not capture the actual precipitation patterns in a satisfactory manner. This results in a less satisfactory simulation of observed soil moisture dynamics when used as input into land surface models (Guo et al., 2006). Therefore, in this study, monthly observation-based climate data are scaled down to daily values. Downscaling precipitation from monthly to daily values is based on the number of wet days per month, assuming the same grid-cell precipitation on each wet day of a month, while daily temperature and cloudiness are obtained by cubic spline interpolation. For precipitation, the most important climatic driver of groundwater recharge, there is another $0.5^{\circ}$ gridded global data set of long duration, the GPCC Full Data Product Version 3, for 1950-2004 (Fuchs et al., 2007). The two different precipitation data sets are based on different methods for the spatial interpolation of observation data. For the CRU data set, 1961-1990 precipitation normals at 19295 stations were combined with time series at less stations of temporally varying numbers to construct gridded time series from anomalies (New et al., 1999, 2000). For the GPCC data set, only the station data available for the month of interest are taken into account, thus losing information on spatial variability from the precipitation normals. For the period 1961-1990, precipitation time series are available for about 15000 stations (Fuchs et al., 2007). The differences between the two precipitation data sets are large at the grid-scale (Fig. 4). For some parts of the world, e.g. the Himalayas, the long-term average precipitation values differ by more than a factor of two, and for many parts of the world, by more than $20 \%$. In the Himalayas, CRU precipitation seems to be shifted towards the Northeast as compared to GPCC. According to CRU, mean annual long-term average precipitation for 1961-1990 is 721 $\mathrm{mm} / \mathrm{yr}$ over the continents, as compared to $708 \mathrm{~mm} / \mathrm{yr}$ according to GPCC. Differences are larger for individual years. It is not possible to judge which of the two data sets better reflects actual precipitation. Therefore, both precipitation data sets are considered to be of equal reliability, and the best estimate of groundwater recharge is assumed to be equal to the mean of the groundwater recharge values obtained by using 


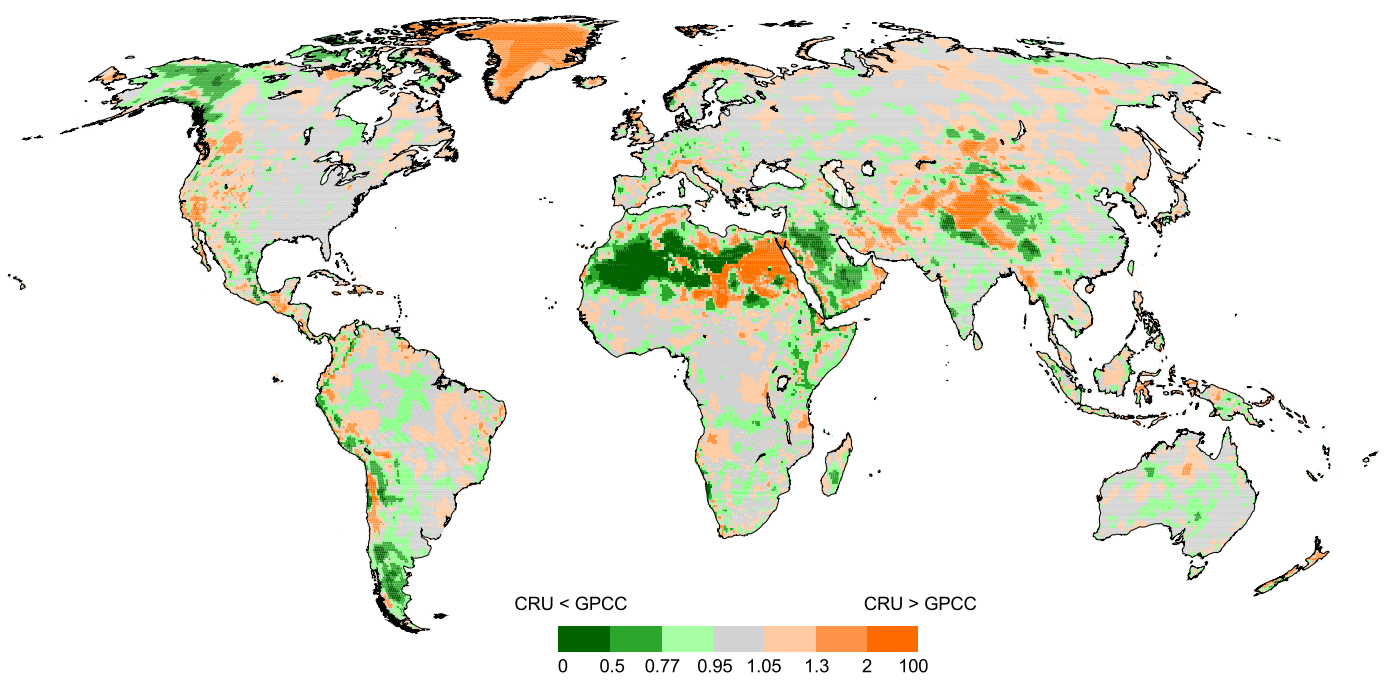

Fig. 4. Difference between the two available $0.5^{\circ}$ global data sets of time series of gridded observed precipitation: ratio of CRU $1961-1990$ mean annual precipitation to GPCC 1961-1990 mean annual precipitation.

the two different precipitation data sets as input to WGHM.

None of the precipitation data sets is corrected for observational errors, i.e. the typical wind-induced undercatch of especially solid precipitation. We developed the following equation to correct the time series of gridded observed monthly precipitation $P_{o}$, using catch ratios of Adam and Lettenmaier (2003):

$P_{c}=P_{o}\left[\left(\frac{1}{C R}-1\right) \frac{R(T)}{R\left(T_{\text {mean }}\right)}+1\right]$

$\begin{array}{ll}P_{c}= & \begin{array}{l}\text { corrected precipitation value }[\mathrm{mm} / \mathrm{month}] \\ C R=\end{array} \\ 0.5^{\circ} \text { gridded mean monthly catch ratio (mea- } \\ \text { sured precipitation as a ratio of actual precip- } \\ \text { itation) for 1979-1998 } \\ \text { snow as a fraction of total monthly precipita- } \\ \text { tion (a function of monthly temperature) } \\ T=\quad \begin{array}{l}\text { temperature of specific month } \\ \text { average temperature 1961-1990 }\end{array}\end{array}$

The mean monthly catch ratios were obtained by analyzing the climatic conditions at 7898 climate stations between 1979 and 1998, and by taking into account the different gauge types that are in use around the world (Adam and Lettenmaier, 2003). In some areas, extremely high values of $C R$ in the data of Adam and Lettenmaier (2003), which are likely due to the interpolation algorithm, were smoothed. Particularly low catch ratios are observed in case of snow. In case of precipitation time series, it is therefore important to correct e.g. precipitation in January 1965 more than in January 1966, if a larger fraction of precipitation fell as snow in January 1965 than in 1966. This adjustment was done using the empirical function $R$ of Legates (1987) which relates snow as a fraction of total monthly precipitation to monthly temperature $T$, with

$$
R=\frac{1}{1+1.61(1.35)^{T}}
$$

Correction of $P_{o}$ was limited to a range between 1 and 2.3. Correction by $R(T) / R\left(T_{\text {mean }}\right)$ overestimates the impact of interannual variability of monthly temperatures on the necessary precipitation correction if catch ratios are not affected by snow, i.e. at high temperatures. If this correction is only applied at mean monthly temperatures below $3^{\circ} \mathrm{C}$, computed long-term average groundwater recharge is not significantly changed. The global value (ensemble mean using GPCC and CRU precipitation data) decreases by only $0.5 \%$, and for $83.3 \%$ and $99.77 \%$ of all grid cells, long-term average groundwater recharge changes by less than 1 and $5 \mathrm{~mm} / \mathrm{yr}$, respectively.

Correction of GPCC 1961-1990 precipitation according to Eq. (2) increased the global mean by $11.6 \%$, from $708 \mathrm{~mm} / \mathrm{yr}$ to $790 \mathrm{~mm} / \mathrm{yr}$, with increases of annual precipitation ranging between a few percent and 30\% in most areas of the globe. The relative changes of the CRU precipitation due to correction are very similar. WGHM was tuned separately with each of the two precipitation data sets.

\section{Results}

\subsection{Groundwater recharge}

The global map of long-term average diffuse groundwater recharge for the period 1961-1990 (Fig. 5a) presents the ensemble mean of two WGHM model runs with either GPCC or CRU precipitation data as input. The mean represents 

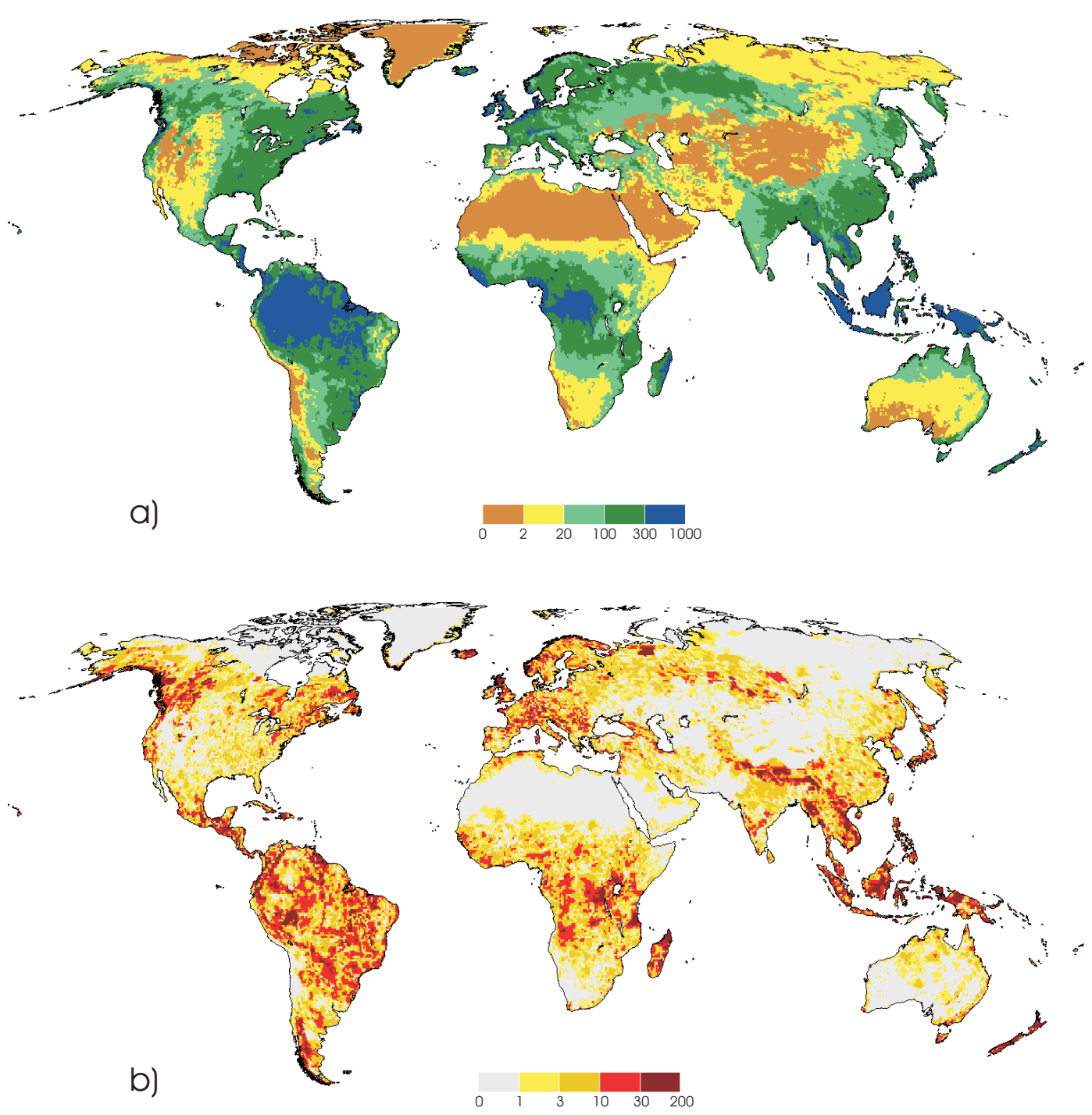

Fig. 5. Long-term average diffuse groundwater recharge for the time period 1961-1990 in mm/yr; ensemble mean of groundwater recharge as computed by two WGHM model runs with either GPCC or CRU precipitation data as input (a). Absolute difference between groundwater recharge computed with either one of the two precipitation data sets and the ensemble mean value, in $\mathrm{mm} / \mathrm{yr}$ (b).

a best estimate because the quality of the two precipitation data sets is judged to be equal. Both precipitation data sets have been corrected for observational errors by the same method. Grid-scale groundwater recharge ranges from 0 to $960 \mathrm{~mm} / \mathrm{yr}$, with the highest values occurring in the humid tropics. Values over $300 \mathrm{~mm} / \mathrm{yr}$ are also computed for some parts of northwestern Europe and the Alps. Europe is the continent with the smallest fraction of regions with groundwater recharge below $20 \mathrm{~mm} / \mathrm{yr}$. Such low values occur in the dry subtropics and in Arctic regions (mainly due to permafrost).

Figure $5 \mathrm{~b}$ shows the uncertainty of estimated groundwater recharge that is due to the use of two different precipitation data sets. The absolute difference between GPCC (or CRU) groundwater recharge per grid cell and the ensemble mean ranges between 0 and $186 \mathrm{~mm} / \mathrm{yr}$, and at the scale of the $0.5^{\circ}$ grid cell, the percent differences can be quite high (compare Figs. 5a and b). The spatial pattern of uncertainty is due to the combination of 1 ) the often very high differences between the precipitation data sets (Fig. 4), and 2) the runoff coefficients and correction factors, which are equal within each river basin and differ between the GPCC and CRU model runs.

The differences between the results for the two precipitation data sets become, in general, smaller with increasing size of the considered area, e.g. for countries (Appendix B) and continents (Table 1). For 50 out of the 165 countries considered, the deviation from the mean was less than $1 \%$, for 62 between 1 and 5\%, for 43 between 5 and $20 \%$ and for 10 between 20 and $80 \%$. Deviations of more than $50 \%$ 
Table 1. Long-term average continental groundwater resources (total and per capita) and total water resources as computed by WGHM for the climate normal 1961-1990. Deviation refers to the absolute difference between water resources as computed with either one of the two precipitation data sets and the ensemble mean value, in percent of the mean.

\begin{tabular}{|c|c|c|c|c|c|c|}
\hline Continent & $\begin{array}{c}\text { Total renewable } \\
\text { water resources } \\
\text { A } \\
{\left[\mathrm{km}^{3} / \mathrm{yr}\right]}\end{array}$ & Deviation & $\begin{array}{c}\text { Renewable } \\
\text { groundwater } \\
\text { resources } \\
\text { B } \\
{\left[\mathrm{km}^{3} / \mathrm{yr}\right]}\end{array}$ & Deviation & $\mathrm{B} / \mathrm{A}$ & $\begin{array}{l}\text { Per capita } \\
\text { renewable } \\
\text { groundwater } \\
\text { resources } \mathrm{e} \\
{\left[\mathrm{m}^{3} / \text { cap yr] }\right.}\end{array}$ \\
\hline Africa & 4065 & 1.8 & 2072 & 1.4 & 51 & 2604 \\
\hline Asia ${ }^{a, b}$ & 13168 & 1.0 & 3247 & 1.6 & 25 & 873 \\
\hline Australia and Oceania & 1272 & 4.2 & 404 & 3.1 & 32 & 14578 \\
\hline Europe $^{\mathrm{a}}$ & 3104 & 1.7 & 1191 & 0.8 & 38 & 1740 \\
\hline North/Central America ${ }^{c}$ & 6493 & 1.0 & 1621 & 0.6 & 25 & 3336 \\
\hline South America & 11310 & 0.3 & 4131 & 0.6 & 37 & 11949 \\
\hline Total land area $\mathrm{d}$ & 39414 & 0.02 & 12666 & 1.1 & 32 & 2091 \\
\hline
\end{tabular}

\footnotetext{
${ }^{a}$ Eurasia is subdivided into Europe and Asia along the Ural; Turkey is assigned to Asia.

${ }^{b}$ Including the whole island of New Guinea.

c Including Greenland.

d Excluding Antarctica.

e Population data based on CIESIN GPWv3 for the year 2000.
}

occurred in case of the arid countries Kuwait, Qatar, Saudi Arabia and Western Sahara (Appendix B). At continental and global scales, the uncertainty of groundwater recharge due to the two different data sets becomes insignificant, except for the dry Australia and Oceania (Table 1).

For all land areas of the Earth, excluding Antarctica, groundwater recharge and thus renewable groundwater resources are estimated to be $12666 \mathrm{~km}^{3} / \mathrm{yr}$, while the continental values range from $404 \mathrm{~km}^{3} / \mathrm{yr}$ for Australia and Oceania to $4131 \mathrm{~km}^{3} / \mathrm{yr}$ for South America (Table 1). Appendix $B$ lists average groundwater recharge in 165 countries with an area of more than $10000 \mathrm{~km}^{2}$.

To estimate the renewable groundwater resources that are potentially available for humans in a specific area, groundwater recharge is divided by the population of this area. The ideal spatial unit for this computation corresponds to the lateral extent of the shallow aquifer which stores the groundwater recharge or the extent of a deep aquifer which is hydraulically connected to the recharge. However, the required spatial information about the groundwater bodies is not available at the global scale. River basins, which are considered to be the most appropriate spatial scale for surface water flow assessments, are not appropriate spatial units for assessing groundwater resources as aquifer boundaries do not necessarily correspond to river basins boundaries. In the case of non-local aquifers, a $0.5^{\circ}$ grid cell is too small a spatial unit, because in many aquifers, a groundwater well in one cell draws water that is hydraulically connected to water in many more cells. Thus, to give an impression of the global distribution of groundwater resources per person, the average values for countries, or, in the case of eleven large countries (Argentina, Australia, Brazil, Canada, China, India, Kazakhstan, Mexico, Mongolia, Russia and USA), for the first level of subnational units are shown in Fig. 6 (borders of countries and subnational units are taken from ESRI, 2004). Population numbers are representative for the year 2000, and are taken from the Gridded Population of the World version 3 (GPWv3) data set (CIESIN, 2005).

Renewable groundwater resources, at that scale of aggregation, range from $8 \mathrm{~m}^{3}$ /(capitayr) for Egypt to more than 1 million $\mathrm{m}^{3}$ (capita yr) for the Falkland Islands. Please note that recharge from surface waters to the groundwater is not counted as groundwater resources here. All countries in Northern Africa and the Near East except Libya have average per-capita groundwater resources of less than $500 \mathrm{~m}^{3} /$ (capita yr). Even humid countries can have per-capita groundwater resources below $1000 \mathrm{~m}^{3} /$ (capita yr) if population density is high, like The Netherlands, Vietnam, Japan or Germany. Per-capita renewable groundwater resources for countries are tabulated in Appendix B. Figure 6 shows that except for Canada and Australia per-capita groundwater resources vary strongly within the large countries that were subdivided. In the USA, the lowest values occur in the Southwest, while in Mexico, the northern parts and the densely populated states in the central part show the smallest per-capita groundwater resources. In Brazil, the difference between the water-rich and population-poor Amazon basin and the rest of the country becomes visible. In Argentina, only the semi-arid western states have low percapita groundwater resources because the semi-arid south- 


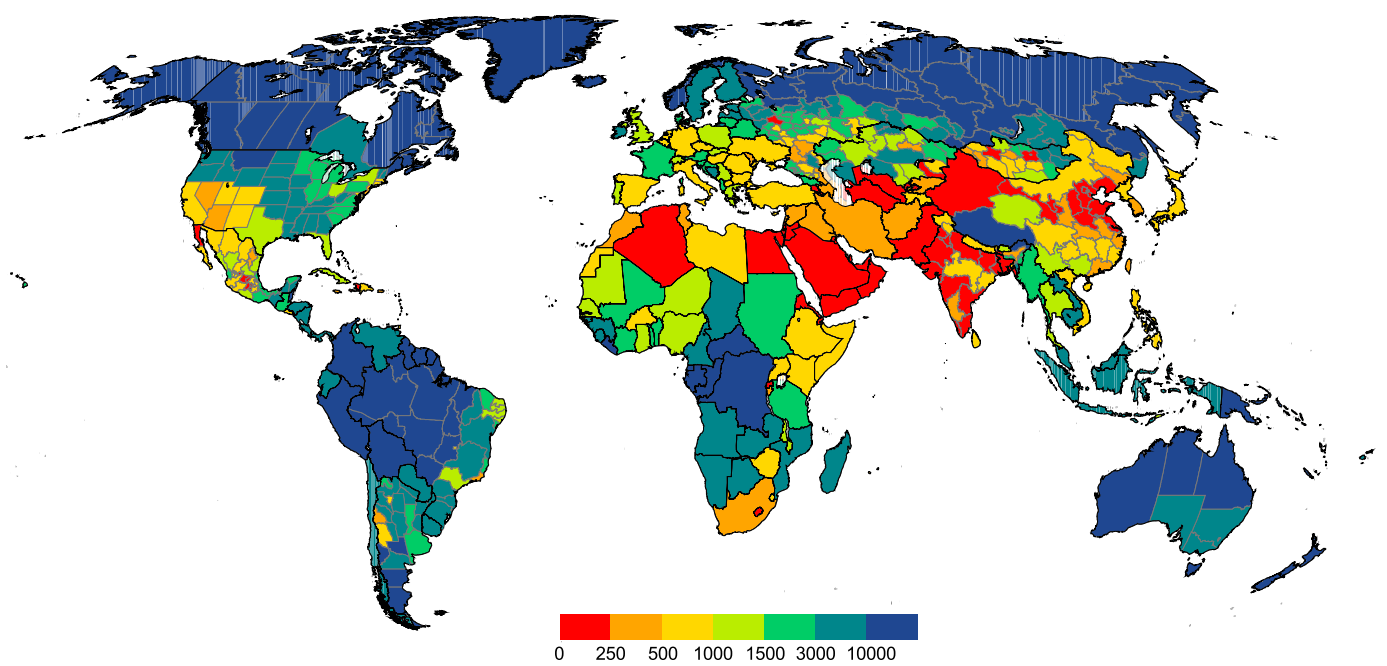

Fig. 6. Per-capita groundwater resources in administrative units, in $\mathrm{m}^{3} /$ (capita yr), as computed by WGHM (ensemble mean using GPCC/CRU precipitation). Groundwater resources are representative for the climate normal 1961-1990, population is representative for the year 2000 .

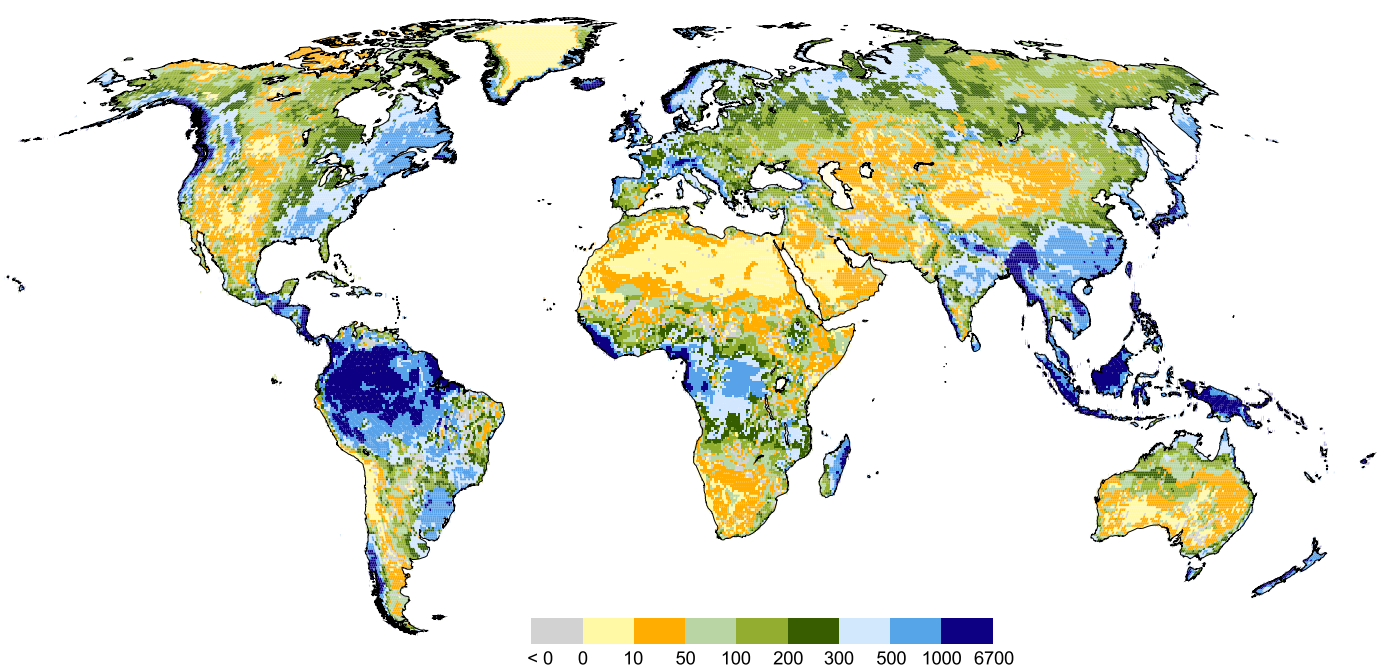

Fig. 7. Long-term average total runoff from land and open water fraction of cell, in $\mathrm{mm} / \mathrm{yr}$, for the time period 1961-1990, as computed by WGHM (ensemble mean using GPCC/CRU precipitation).

ern states have low population densities. In Russia, Mongolia, Australia and Canada, population density dominates the spatial pattern. Of the large countries, India has the lowest per-capita groundwater resources, with $273 \mathrm{~m}^{3} /$ (capita yr) on average (Appendix B), while most federal states are below $250 \mathrm{~m}^{3} /($ capitayr). The average value for China is $490 \mathrm{~m}^{3} /($ capita yr), but some densely populated northern states as well as the semi-arid Northwest show per-capita groundwater resources below $250 \mathrm{~m}^{3} /$ (capita yr).

In 2000, average per-capita groundwater resources were $2091 \mathrm{~m}^{3} /($ capita yr) globally (Table 1). Australia and Oceania, due to the low population density, shows the highest con- tinental value, while Asia has the lowest value due to its high population density, even though it is the continent with the second highest groundwater resources (in $\mathrm{km}^{3} / \mathrm{yr}$ ) (Table 1).

\subsection{Groundwater recharge as compared to total runoff}

Net cell runoff (Sect. 2.1.1) is the best estimate of total water resources of a cell. It includes runoff from land, lakes and wetlands, and it takes into account the decrease of runoff due to evapotranspiration from open water surfaces. Therefore, under semi-arid conditions, net cell runoff can be less than zero if water flows into the cell's lakes and wetlands from upstream. Net cell runoff is equal to the internally renewable 


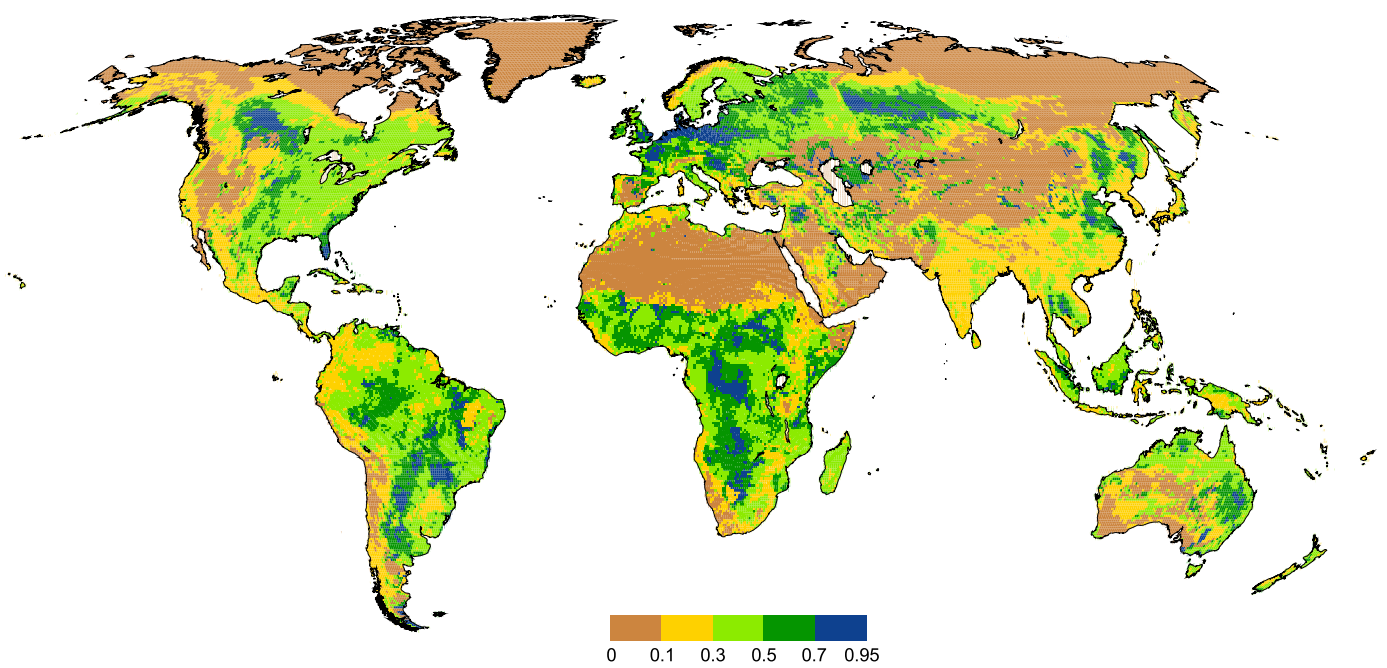

Fig. 8. Groundwater recharge as a fraction of total runoff from land (1961-1990), as computed by WGHM (ensemble mean using GPCC/CRU precipitation).

water resources of the cell if consumptive water use in the cell and upstream has been set to zero in the model run. Figure 7 shows the global distribution of net cell runoff for the case of no consumptive water use. Total and continental values of total renewable water resources are listed in Table 1. Compared to values of Döll et al. (2003), net cell runoff is significantly higher in most northern snow-dominated areas (Canada, Scandinavia, Siberia) due to the precipitation correction applied here. This is the main reason that the global estimate of total water resources, $39414 \mathrm{~km}^{3} / \mathrm{yr}$, is $7 \%$ larger than the value presented in Döll et al. (2003). Besides, the spatial pattern of runoff is more varied than before, particularly in Siberia where many more river discharge stations have been available for tuning WGHM version 2.1f.

Total internally renewable water resources of a country are equal to the sum of net cell runoff of all cells within the country. They can be smaller than the groundwater resources, or even negative. The latter is the case in Botswana, Egypt and Malawi, where more water evapotranspirates from land, wetlands and lakes than falls as precipitation inside the country (Appendix B). The groundwater resources of Chad, Iraq, Mali, Senegal, Sudan, The Gambia, Uganda and Zambia are larger than the total internally renewable water resources (Appendix B) due to evaporation of external water from open water surfaces. In the above countries as well as other semi-arid countries that are strongly affected by evaporation from surface waters (e.g. Azerbaijan, Burkina Faso and Central African Republic), groundwater use may have the potential to decrease evaporation from surface waters and thus to increase total water resources. With 86 and $74 \%$, The Netherlands and Denmark are the countries with the largest percentage of groundwater recharge (not caused by evapotranspirative losses from lakes and wetlands), followed by Poland and The Republic of Congo, with values over $70 \%$
(Appendix B). 21 countries have ratios between 50 and $70 \%$, and 13 dry countries as well as Greenland, Svalbard, Nepal and Bhutan have ratios below $15 \%$ (Appendix B).

Globally, $32 \%$ of the total water resources are groundwater resources (Table 1). Asia and North and Central America are the continents with the smallest percentage $(25 \%)$, while in Africa groundwater resources account for $51 \%$ of the total water resources. As explained above, this is mainly due to evaporative losses from open water surfaces which decreases total water resources and thus increases the percentage of groundwater resources.

Groundwater recharge as a fraction of total runoff from land (GWRF) is analyzed to identify areas where water resources are relatively vulnerable to pollution and seasonal and inter-annual flow variability because a relatively large part of runoff rapidly drains to surface waters. Total runoff from land is the sum of groundwater recharge and fast surface and subsurface runoff (Fig. 1) and does not include evapotranspiration from surface water. GWRF is equal to the baseflow index if all groundwater recharge reaches the river. GWRF ranges from 0 to 0.95 at the scale of grid cells (Fig. 8). Regions with GWRF of more than 0.7 include plains in Europe and the Asian part of Russia, and some other lowland areas scattered around the globe. GWRF below 0.3 occur in most semi-arid and arid regions, except those with a fine soil texture (which is due to the groundwater recharge algorithm applied in WGHM, Sect. 2.1.2), in mountainous areas like the Alps or the Ural, in the Arctic (due to permafrost) and in the Asian monsoon regions, where only a small part of heavy precipitation serves to recharge the groundwater. These regions are particularly vulnerable to seasonal and inter-annual precipitation variability and water pollution. 

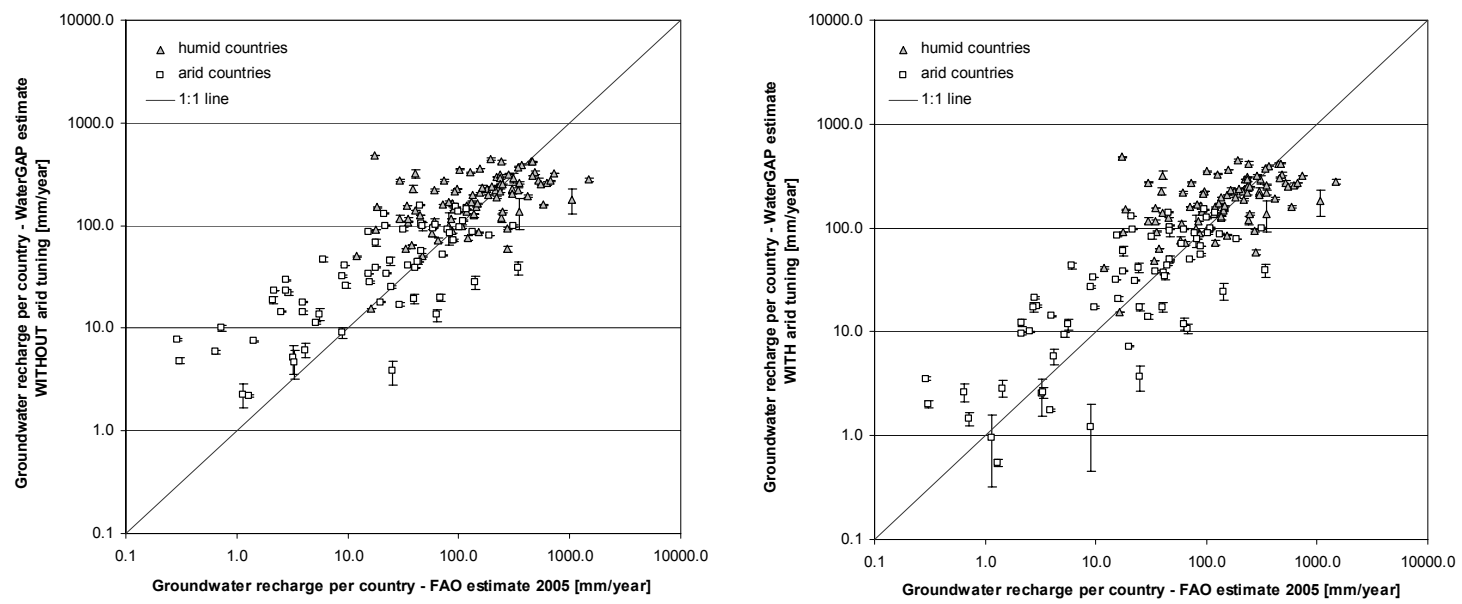

Fig. 9. Comparison of computed groundwater recharge per country (ensemble mean and range) to independent estimates of FAO (2005), in $\mathrm{mm} / \mathrm{yr}$. With the modified groundwater recharge algorithm for semi-arid areas (right), the bias towards an overestimation of groundwater recharge in "semi-arid" countries (left) is almost eliminated. Here, countries are called "semi-arid" if more than $34 \%$ of the country's cells are semi-arid.

\section{Quality of computed groundwater recharge estimates}

While the quality of simulated river discharge can be assessed easily by comparison to discharge as observed at gauging stations, it is much more difficult to assess the quality of simulated groundwater recharge, as groundwater recharge cannot be measured directly, and there are no longterm observations at all. Thus, a quality assessment of simulated groundwater is hampered by the generally high uncertainty of independent estimates of groundwater recharge (compare Sect. 1).

Comparing simulated grid cell groundwater recharge with estimates of groundwater recharge from chloride profiles in semi-arid areas, we concluded that WGHM computes an unbiased estimate of groundwater recharge under semiarid conditions (Fig. 3). A comparison against estimates of groundwater recharge in countries is possible, as FAO (2005) provides estimates for 157 countries. However, most of these values cannot be considered to be reliable, as they are not based on measurements or well-founded computations (see discussion in Sect. 1), such that they are only a very weak basis for model validation. Comparing simulated groundwater recharge with the independent estimates in Fig. 9, it can be seen that modification of the groundwater recharge algorithm for semi-arid areas almost eliminates the bias towards an overestimation of groundwater recharge in "semi-arid" countries (70 out of the 157 countries). Here, countries are called "semi-arid" if more than $34 \%$ of the country's cells are defined as semi-arid in this investigation (comp. Sect. 2.1.2). The modification of the WGHM groundwater recharge algorithm reduces simulated total groundwater recharge in semi-arid countries that are included in the FAO (2005) data set from 3690 to $3305 \mathrm{~km}^{3} / \mathrm{yr}$, as compared to $3229 \mathrm{~km}^{3} / \mathrm{yr}$ according to FAO (2005). Modeling efficiency (or Nash-Sutcliffe coefficient; Janssen and Heuberger, 1995) remains low, even though it improves from 0.16 to 0.20 for recharge in $\mathrm{mm} / \mathrm{yr}$ (and from 0.89 to 0.90 for recharge in $\mathrm{km}^{3} / \mathrm{yr}$ ).

The analysis of modeling efficiency obviously relies on the highly uncertain estimates of groundwater resources per country by FAO (2005). For Finland, Germany and the USA, FAO estimates were replaced in Fig. 9. Average groundwater recharge for Finland of $85 \mathrm{~mm} / \mathrm{yr}$ (Lavapuro et al., 2007) appears to be more realistic than the FAO value of $7 \mathrm{~mm} / \mathrm{yr}$ (given a precipitation of $660 \mathrm{~mm} / \mathrm{yr}$ ), and for Germany the recently derived value of $135 \mathrm{~mm} / \mathrm{yr}$ (Jankiewicz et al., 2005) was used instead of the FAO-value of $128 \mathrm{~mm} / \mathrm{yr}$. For the USA, the WRI (2000) value replaced the FAO (2005) value as the latter is twice as high as the first (and the WGHM value). In FAO (2005), this value is related to a total runoff value that is equal to $54 \%$ of total precipitation, while the computed WGHM total runoff, which is bounded by many discharge observations, is only $37 \%$ of precipitation. However, there remain many countries for which the independent estimates of groundwater resources seem to be unrealistic. One example is the United Kingdom, with groundwater resources according to FAO (2005) of only $40 \mathrm{~mm} / \mathrm{yr}$, as compared to $590 \mathrm{~mm} / \mathrm{y}$ surface water resources, whereas WGHM computes groundwater resources of $322 \mathrm{~mm} / \mathrm{yr}$ and total water resources of $792 \mathrm{~mm} / \mathrm{yr}$. While for Brunei Darussalam, with a precipitation of $2700 \mathrm{~mm} / \mathrm{yr}$, groundwater recharge is estimated at only $17 \mathrm{~mm} / \mathrm{yr}$ by FAO, for Réunion, with a comparable precipitation of $3000 \mathrm{~mm}$, FAO provides an estimate of $1056 \mathrm{~mm} / \mathrm{yr}$.

For the 87 humid countries, modeling efficiency is 0.11 for recharge in $\mathrm{mm} / \mathrm{yr}\left(0.86\right.$ for recharge in $\left.\mathrm{km}^{3} / \mathrm{yr}\right)$, whereas 

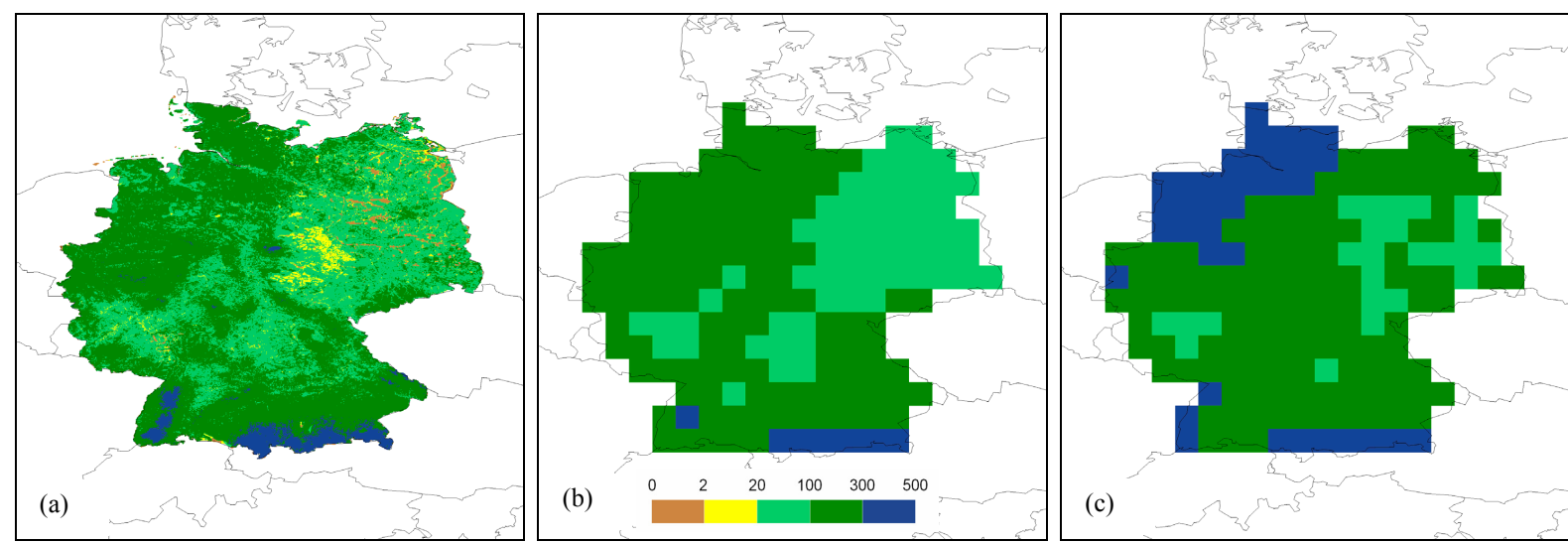

Fig. 10. Groundwater recharge in Germany, in mm/yr, as computed by Jankiewicz et al. (2005, their Fig. 9) with a spatial resolution of $1 \mathrm{~km}$ by $1 \mathrm{~km}$ for 1961-1990 (a); aggregated to a spatial resolution of $0.5^{\circ}$ (b); groundwater recharge as computed with WGHM for the same spatial resolution and time period (c).

the overall modeling efficiency for all countries is 0.33 (for $\mathrm{mm} / \mathrm{yr}$ ) and 0.87 (for $\mathrm{km}^{3} / \mathrm{yr}$ ). Of the countries with a groundwater recharge of more than $100 \mathrm{~km}^{3} / \mathrm{yr}$, computed and independent estimates differ by less than $10 \%$ in case of Argentina, Cameroon, Colombia, Myanmar, Peru, Russia and USA. WHGM overestimates the independent estimates by more than $10 \%$ in case of Bolivia, Brazil, Canada, Democratic Republic of Congo, and Indonesia, and underestimates them in case of Chile, China, Guyana, India, Mexico, Philippines, and Republic of Congo. In conclusion, WGHM can certainly not explain the independent groundwater resources estimates, but it is not clear to what extent this is equal to not being able to model reality. Possibly, the soil texture-specific maximum groundwater recharge values (infiltration capacity) in Eq. (1) and Table A1 should be increased considering that groundwater recharge in most monsoon countries is underestimated (but overestimated in Indochina and Indonesia).

Simulated groundwater recharge in those humid countries that are included in the FAO data set is $8912 \mathrm{~km}^{3} / \mathrm{yr}$, as compared to $7299 \mathrm{~km}^{3} / \mathrm{yr}$ according to FAO. Computed global groundwater recharge of $12666 \mathrm{~km}^{3} / \mathrm{yr}$ (Table 1) is $10 \%$ larger than the value estimated by L'vovich (1979) by a global-scale baseflow analysis for almost 1500 rivers (800 of them in the former Soviet Union). However, no discharge data had been available to L'vovich for $80 \%$ of South America, $20 \%$ of Africa (not counting the Sahara and the Kalahari), $60 \%$ of Australia (not counting the desert), and some parts of Asia and Canada.

For Germany, computed long-term average groundwater recharge at the scale of $0.5^{\circ}$ grid cells can be compared to values that were obtained by multiple regression with a spatial resolution of $1 \mathrm{~km}$ by $1 \mathrm{~km}$, using baseflow as derived from 106 observed hydrographs (Jankiewicz et al., 2005). For the whole of Germany, average groundwater recharge and total runoff from land are $135 \mathrm{~mm} / \mathrm{yr}$ and $327 \mathrm{~mm} / \mathrm{yr}$ (Jankiewicz et al., 2005) vs. $201 \mathrm{~mm} / \mathrm{yr}$ and
$316 \mathrm{~mm} / \mathrm{yr}$ (WGHM), respectively. Average baseflow coefficients are 0.41 (Jankiewicz et al., 2005) and 0.64 (WGHM). Thus, both average groundwater recharge and baseflow coefficient for Germany are overestimated by WGHM. In particular, groundwater recharge in the wet northwestern part is overestimated (Fig. 10). This may originate from the fact that artificial drainage for agricultural purposes, which increases fast subsurface runoff, is not taken into account by WHGM but by Jankiewicz et al. (2005). Besides, groundwater recharge in the eastern part of Germany is overestimated which is partially due to an overestimation of total runoff particularly in the North, and partially to higher baseflow indices in WGHM. Baseflow indices (BFI) of Jankiewicz et al. are mainly in the range of 0.5 to 0.75 (Jankiewicz et al., 2005, their Fig. 10) while BFIs of WGHM are mainly in the range of 0.75 to 0.95 . Besides, Jankiewicz et al. (2005) reduced groundwater recharge where distance to groundwater is small, i.e. in floodplains (Fig. 10a).

The larger WGHM BFIs, however, fit well to the values of Haberlandt et al. (2001) who derived BFIs for the German Elbe basin, which covers most of eastern Germany. Haberlandt et al. (2001) also regionalized BFIs by multiple regression. For most subbasins in the central and northern Elbe basin, they obtained BFIs $>0.8$ (Fig. 11 in Haberlandt et al., 2001). The difference of BFIs between Haberlandt et al. (2001) and Jankiewicz et al. (2005) are most likely due to the different methods of deriving baseflow that serves as the basis for multiple regression and regionalization. While Jankiewicz et al. (2005) used an automatic method for hydrograph separation based on daily river discharge, Haberlandt et al. (2001) used baseflow as computed by two models which simulated discharge in 25 small subbasins of the Elbe in a satisfactory manner. While WGHM underestimates the baseflow indices of Jankiewicz et al. (2005) in the Elbe river basin, WGHM baseflow indices are similar to those of Haberlandt et al. (2001). 


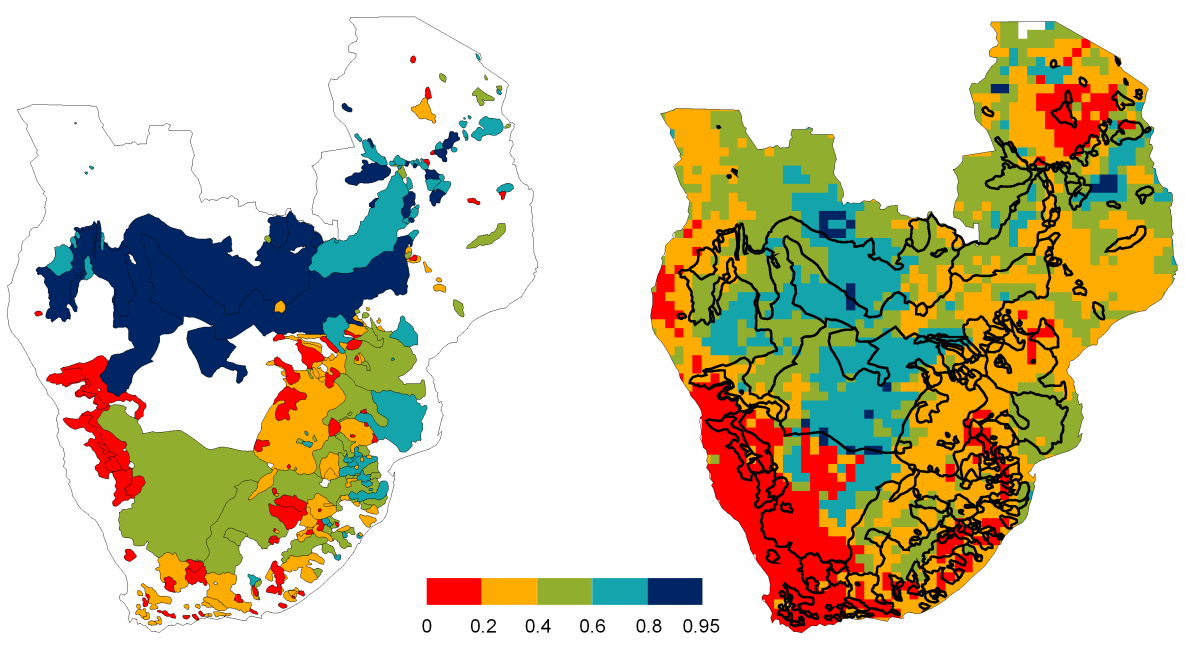

Fig. 11. Baseflow indices at discharge observation stations in Southern Africa, mapped onto the pertaining basins (Bullock et al., 1997, their Fig. 4.35) (left); groundwater recharge as a fraction of total runoff from land as computed with WGHM, with polygon outlines of Bullock et al. (1997) for easier comparison (right). Please note that the polygon outlines are not basin boundaries but boundaries of polygon with the same color in the figure on the left.

Finally, WGHM baseflow coefficients for Southern Africa are compared to baseflow indices from hydrograph separation at discharge observation stations in Southern Africa, mapped onto the pertaining basins (Bullock et al., 1997, their Fig. 4.35). However, on their figure, the basin outlines cannot be recognized such that it is not possible to show the corresponding pattern of average WGHM baseflow indices for the basins. Figure 11 shows how the baseflow indices as computed for individual grid cells by WGHM compare to the average basin BFIs of Bullock et al. (1997). The colors of small polygons can be compared most directly, while for larger polygons, the grid cell values within the polygon must be averaged. The spatial pattern of BFI on both maps is somewhat consistent, with values below 0.1 in the westernmost basins in Namibia and values between 0 and 0.3 in southern and eastern central South Africa. Towards the more humid North, in Angola and Zambia, both maps show larger BFI values, but WHGM values remain between 0.60.8 while the Bullock et al. values are above 0.8 .

Groundwater recharge as computed by WGHM (using GPCC precipitation data) has been included in WHYMAP Global Map of Groundwater Resources (with some smoothing for cartographic reasons). During the map development process, groundwater recharge values were commented on by more than 30 groundwater experts from all around the globe (W. Struckmeier, personal communication, 2008). As a result, the depicted groundwater recharge was increased in two karst areas in former Yugoslavia and in Mexico. Otherwise, the experts did not identify, in the regions they were familiar with, any divergences from the groundwater recharge values they considered plausible.

\section{Conclusions}

The global $0.5^{\circ}$ by $0.5^{\circ}$ data set of long-term average groundwater recharge presented here is unique in that it combines state-of-the-art global scale hydrological modeling with independent information on small-scale groundwater recharge in semi-arid and arid areas in an ensembles approach which takes into account and quantifies the uncertainty due to available precipitation data. Basin-specific tuning of the WaterGAP Global Hydrology Model WGHM against river discharge at 1235 stations world-wide helps to compute reasonable estimates of total runoff from land. Inclusion of a large number of spatially variable climatic and physio-geographic characteristics (including land cover, soil water holding capacity, soil texture, relief, hydrogeology, permafrost/glacier) allows a well-founded estimate of groundwater recharge distribution. Consideration of reliable information on long-term average groundwater recharge at selected semi-arid locations world-wide made it possible to obtain an unbiased estimate of groundwater recharge in semi-arid areas. Finally, using the mean of two groundwater recharge estimates as obtained by applying two different and equally uncertain global precipitation data sets make the resulting groundwater recharge data set more robust, while at the same time uncertainty estimates are provided.

Due to the scarcity of reliable independent information on groundwater recharge at all scales, but particularly at the scale of countries or subnational units, it is difficult to judge how well the computed groundwater recharge estimates correspond to reality. In particular, a comparison to country estimates of groundwater resources as compiled by FAO (2005) does not help. In most cases the method of estimation is unknown and likely to be very rough, while in 
some cases the listed renewable groundwater resources are obviously not defined as being equivalent to groundwater recharge. A comparison of independent estimates of groundwater recharge or rather baseflow coefficients that were derived using well-founded scientific methods (Jankiewicz et al., 2005; Haberlandt et al., 2005) showed that uncertainty of baseflow estimation from river discharge may lead to significantly different estimates of meso-scale baseflow indices and thus groundwater recharge. At the global scale, WGHM would overestimate groundwater recharge by about $10-20 \%$ if the base-flow derived estimates of L'vovich (1979) and the FAO country values were to be trusted.

A problem with the WGHM groundwater recharge estimation method is that there are sharp boundaries between semi-arid/arid and humid zones which lead to rather abrupt reductions of computed groundwater recharge at the boundaries. In semi-arid zones close to the boundaries groundwater recharge may be underestimated (unless soil texture is fine).

In the future, artificial drainage will be taken into account based on a global data set of artificially drained agricultural areas (spatial resolution $0.5^{\circ}$ ) because groundwater recharge is reduced in these areas. According to the data set of Feick et al. (2005), 1.67 million $\mathrm{km}^{2}$ are drained world-wide, i.e. $1.2 \%$ of the global land area without Greenland and Antarctica. Further validation and improvement of the WGHM groundwater recharge model requires an increased number of reliable estimates of groundwater recharge. A large number of independent estimates of smallscale groundwater recharge in semi-arid areas, compiled by Scanlon et al. (2006), will be evaluated. Validation and improved modeling of groundwater recharge in humid areas is hampered by uncertainties of hydrograph separation.

The presented diffuse groundwater recharge estimates can be regarded as renewable groundwater resources. It is important to note, however, that exploitation of the total groundwater recharge of an aquifer is not possible without very strong impacts on ecosystems and other water users. Withdrawal of a sizeable part of the groundwater recharge already leads to significant drawdown of the water table, with ensuing consequences e.g. for wetlands, and a decrease of streamflow. Thus groundwater recharge is the uppermost limit of sustainably exploitable groundwater resources.
Table A1. Slope classes and the relief-related groundwater recharge factor.

\begin{tabular}{llll}
\hline slope class & slope [\%] & relief $r_{\text {avg }}$ & $f_{r}$ \\
\hline 1 & $0-2$ & 10 & 1 \\
2 & $2-5$ & 20 & 0.95 \\
3 & $5-8$ & 30 & 0.90 \\
4 & $8-16$ & 40 & 0.75 \\
5 & $16-30$ & 50 & 0.60 \\
6 & $30-45$ & 60 & 0.30 \\
7 & $>45$ & 70 & 0.15 \\
\hline
\end{tabular}

\section{Appendix A}

\section{Description of factors in the groundwater recharge model of WGHM}

The following sections describe how the factors in the groundwater recharge model as given by Eq. (1) have been quantified, providing methods and data sources.

\section{A1 Relief}

Based on the GTOPO30 digital elevation model with a resolution of around $1 \mathrm{~km}$ (USGS EROS data center), IIASA produced a map of slope classes with a resolution of 5 min (data provided by Günther Fischer, February 1999) which includes the fraction of each cell that is covered by a certain slope class. Seven slope classes are distinguished (Table A1). The 5 -min-map was aggregated and mapped onto the $0.5^{\circ} \times 0.5^{\circ}$ land mask, such that the percentage of each slope class with respect to the total land area of each $0.5^{\circ}$ cell is produced. An "average relief" $r_{\mathrm{avg}}$, ranging from 10 to 70 , is computed as

$r_{\text {avg }}=\sum_{i=1}^{7}$ slope $^{\operatorname{class}_{i}} * 10 * \operatorname{frac}_{i}$

frac $_{i}=$ areal fraction of slope class $i$ within the $0.5^{\circ}$ cell.

The relief-related groundwater recharge factor $f_{r}$ for each slope class is given in Table A1. For each cell with an average relief $r_{\text {avg }}$, the respective value for $f_{r}$ is obtained by linear interpolation.

\section{A2 Texture}

Soil texture does not only determine the factor $f_{t}$ in Eq. (1), but also the maximum infiltration rate $R_{g \text { max }}$. Soil texture is derived from the FAO Digital Soil Map of the World and Derived Soil Properties (FAO, 1995). The digital map shows, for each $5^{\prime}$ by $5^{\prime}$ raster cell, the soil mapping unit. For each of the 4931 soil mapping units, the following information is provided: 
Table A2. Soil texture classes and the texture-related groundwater recharge factors.

\begin{tabular}{llc}
\hline FAO soil texture class & texture value & $\begin{array}{c}R_{g} \max \\
{[\mathrm{mm} / \mathrm{d}]}\end{array}$ \\
\hline $\begin{array}{l}\text { coarse: } \\
\text { sands, loamy sands and sandy loams with less than 18\% clay and more } \\
\text { than } 65 \% \text { sand } \\
\text { medium: }\end{array}$ & 10 & 1 \\
$\begin{array}{l}\text { sandy loams, loams, sandy clay loams, silt loams, silt, silty clay loams } \\
\text { and clay loams with less than 35\% clay and less than 65\% sand; the sand } \\
\text { fraction may be as high as } 82 \% \text { if a minimum of 18\% clay is present } \\
\text { fine: } \\
\text { clays, silty clays, sandy clays, clay loams and silty clay loams with more } \\
\text { than } 35 \% \text { clay } \\
\text { rock or glacier (in 100\% of cell land area) }\end{array}$ & 30 & 3 \\
\hline
\end{tabular}

Table A3. Hydrogeological units relevant for groundwater recharge and the aquifer-related groundwater recharge factors.

\begin{tabular}{llll}
\hline Hydrogeological units & unit & $f_{a}$ & $\begin{array}{c}f_{a} \text { in hot and } \\
\text { humid climates* }\end{array}$ \\
\hline $\begin{array}{l}\text { Cenozoic and Mesozoic sediments } \\
\text { with high hydraulic conductivity }\end{array}$ & 1 & 1 & 1 \\
$\begin{array}{l}\text { Paleozoic and Precambrian sediments y } \\
\text { with low hydraulic conductivit }\end{array}$ & 2 & 0.7 & 0.8 \\
$\begin{array}{l}\text { non-sedimentary rocks with } \\
\text { very low hydraulic conductivity }\end{array}$ & 3 & 0.5 & 0.7 \\
\hline
\end{tabular}

* Average annual temperature more than $15^{\circ} \mathrm{C}$ and average annual precipitation more than 1000 mm (average climatic conditions $1961-$ 1990).

- names of up to 8 soil units that constitute the soil mapping unit

- the area of each soil unit in percent of the total area of the soil mapping unit

- the area of each soil unit belonging to one of three texture classes and to one of three slope classes

The soil texture provided by FAO is only representative for the uppermost $30 \mathrm{~cm}$ of the soil. We assigned a texture value of 10 to coarse texture, a value of 20 to medium and a value of 30 to fine texture (Table A2). Based on the FAO information, an areally weighted average texture value was computed for the $5^{\prime}$ cells, which was then averaged for land area of each $0.5^{\circ}$ cell. For the following soil units, texture was not given: dunes, glacier, bare rock, water, and salt. The texture value of dunes was set to 10 . All other four soil unit types were not taken into account for computing the areal averages (the bare rock extent in the FAO data set appears to be much too small). Therefore, in a cell with e.g. $20 \%$ water or bare rock, the texture value of the cell is 15 if $40 \%$ of the area is covered with coarse soils and $40 \%$ with medium soils. If the total cell area is water, the texture value is set to 0 ; if it is bare rock or glacier (only very few cells), the texture value equals 1. In these cases, surface runoff is assumed to be equal to total runoff. For some cells (Greenland and some islands), no texture data are provided by FAO. In this case, the texture was assumed to have a texture value of 20 .

\section{A3 Hydrogeology}

A global hydrogeological map does not exist. Only for Europe and Africa, there are hydrogeological maps, which, however, use very different classifications. The Hydrogeological Map of Pan-Europe (RIVM, 1991) distinguishes among areas with good, modest, poor and no hydraulic conductivity. A hydrogeological map of Africa (UN, 1988) was derived from a geological map and only gives information on porosity but not on the more important hydraulic conductivity. A map of groundwater resources in Africa (UNDTCD, 1988) provides additional information on extensive unconfined and confined sedimentary aquifers and local, fragmented fractured aquifers. 
Table A4. Permafrost extent classes.

\begin{tabular}{lll}
\hline $\begin{array}{l}\text { Permafrost extent class according to original } \\
\text { permafrost map }\end{array}$ & $\begin{array}{l}C_{p g} \text { corresponding to } \\
\text { each class [\%] }\end{array}$ & $f_{p g}$ \\
\hline continuous extent of permafrost $(90-100 \%)$ & 95 & 0.05 \\
discontinuous extent of permafrost $(50-90 \%)$ & 70 & 0.3 \\
sporadic extent of permafrost $(10-50 \%)$ & 30 & 0.7 \\
isolated patches of permafrost $(0-10 \%)$ & 5 & 0.95 \\
areas without occurrence of permafrost & 0 & 1 \\
glacier & 100 & 0 \\
\hline
\end{tabular}

On the global scale, only geological maps do exist. The digital Generalized Geological Map of the World (Canadian Geological Survey, 1995) provides, on a scale of 1:35 million, information on the rock type and the rock age. Rock type classes are "mainly sedimentary", "mainly volcanic", "mixed sedimentary", "volcanic and volcaniclastic plutons", "intrusive and metamorphic terranes", "tectonic assemblages, schist belts and melanges", "ice cap (Greenland)". From this map, the dominant rock type and rock age for the land area of each $0.5^{\circ} \times 0.5^{\circ}$ cell was assigned to the respective cell.

However, this rock type classification is not very helpful for estimating where groundwater recharge is relatively high and where not, as rock type classes only show a low correlation with the hydraulic conductivity of the rock. In particular, sedimentary rocks include both sands and clays, which have extremely different hydraulic conductivities. For nonsedimentary rocks, the degree of fracturing is decisive for the hydraulic conductivity, and this information is not given either. For Europe, the rock types in combination with the rock ages were compared to the Hydrogeological Map of PanEurope. It appears that all rock types except the type "mainly sedimentary" correlate to some degree with areas of poor or no hydraulic conductivity. The "mainly sedimentary" rock type corresponds mainly to good or modest hydraulic conductivity if the rock age is either Cenozoic or Mesozoic. Paleozoic sedimentary rocks can have any hydraulic conductivity, while Precambrian sedimentary rocks mostly have poor or no permeability. Based on this comparison to the Hydrogeological Map of Pan-Europe, only a very rough classification of hydrogeological units relevant for groundwater recharge appears to be appropriate (Table A3). This classification was checked against the maps for Africa, and no systematic error became apparent.

High temperature and precipitation enhances weathering. Therefore, groundwater recharge is assumed to be higher in warm and humid climates. The aquifer-related recharge factors $f_{a}$ are modified based on the long-term (1961-1990) average annual temperature and precipitation in each cell (Table A3).
A4 Permafrost and glaciers

It is assumed that there is no groundwater recharge in the case of permafrost and glaciers. Therefore, a data set was produced that provides the percentage of the land area of each cell that is underlain by permafrost or covered by glaciers. The higher this percentage is the smaller is the fraction of total runoff that recharges the groundwater.

Brown et al. (1998) provide digital data for the extent of permafrost on the Northern Hemisphere, including information on glaciers in North America and the Arctic islands (like Spitzbergen and Nowaja Semlja). Table A4 lists the five classes of permafrost extent according to Brown et al. (1998). To each of the five classes, an exact percentage of the area affected by permafrost $C_{p g}$ was assigned, and $f_{p g}$ was set to $\left(100-C_{p g}\right) / 100$. For North America and the Arctic islands, some map units within permafrost areas are not assigned to any permafrost extent class but are classified as glaciers. However, on the rest of the map, e.g. in Norway or in the Himalayas, no information on glaciers is given, and the permafrost areas are continuous. The glacier areas in North America and the Arctic islands were assigned a value of $C_{p g}=100 \%$.

The permafrost map was rasterized on a grid of $1 / 18^{\circ} \times 1 / 18^{\circ}$, each cell being assigned to one of the five classes in Table A4 or to the class "glacier". Then, the areal percentage of permafrost and glacier coverage within each $0.5^{\circ}$ cell was determined as the average of the $C_{p g}$-values of the $1 / 18^{\circ} \times 1 / 18^{\circ}$ cells that are land cells on Brown et al. (1998) map.

For the Southern Hemisphere, no reliable maps of permafrost areas could be found, which is due to the sporadic occurrence of permafrost and the little research done. Thus, the impact of permafrost on groundwater recharge was neglected for the Southern Hemisphere.

In the next step, the glacier coverage for the land areas outside North America and the Arctic was added. The glacier coverage was derived from the World Glacier Inventory (Hoelzle and Haeberli, 1999); in this inventory, the approximate location of the center of each glacier and its areal extent is provided. Glaciers with an areal extent of at 
least $1 \mathrm{~km}^{2}$ were taken into account, which resulted in 8998 glaciers globally (outside North America and the Arctic islands, and not considering Greenland and the Antarctic). For each $0.5^{\circ}$ cell, the areal extents of all glaciers located within the cell were summed up. When a cell only has glaciers and no permafrost, the fraction of the glacial area with respect to the total land area of the cells is equal to the value $C_{p g}$. If there are both permafrost and glaciers (outside North America and the Arctic islands) within a $0.5^{\circ}$ cell, $C_{p g}$ is computed as

$C_{p g}=\frac{100 * A_{g l}+C_{p g}(\text { permafrost }) *\left(A_{\text {land }}-A_{g l}\right)}{A_{\text {land }}}$

$A_{g l}=$ sum of all glacial area in a $0.5^{\circ}$ cell $\left[\mathrm{km}^{2}\right]$

$C_{p g}$ (permafrost) $=$ average $C_{p g}$-value due to permafrost

$A_{\text {land }}=$ land area of $0.5^{\circ}$ cell $\left[\mathrm{km}^{2}\right]$

The factor $f_{p g}$ is assumed to be linearly related to $C_{p g}$, with $f_{p g}=1$ if $C_{p g}=0 \%$ (no decrease of groundwater recharge due to glaciers and permafrost if neither of them occurs) and $f_{p g}=0$ if $C_{p g}=100 \%$ (no groundwater recharge if the cell is totally covered by glaciers).

\section{Appendix B}

\section{Renewable groundwater resources and total renewable water resources of countries as computed by WGHM for the climate normal 1961-1990}

The internally renewable water resources of countries are equal to the difference of long-term average precipitation and evapotranspiration within a country. In semi-arid countries, it can be negative if inflow from other countries evapotranspirates within the country. The internally renewable groundwater resources are equal to the groundwater recharge within the countries; they are always positive. In Table B1, the means of the total and groundwater resources computed with GPCC and CRU precipitation data for 1961-1990 are listed together with the percent deviation from the mean (difference between resources as computed with either one of the two precipitation data sets and the ensemble mean value), which shows the uncertainty of the model estimates due to the uncertain precipitation input data. B/A represents groundwater resources in percent of total water resources. In some semi-arid countries, it can be larger than $100 \%$ or negative because total water resources are reduced by evapotranspiration from surface water bodies. Only countries with an area of more than $10000 \mathrm{~km}^{2}$ are listed. 
Table B1. Renewable groundwater resources and total renewable water resources of countries as computed by WGHM for the climate normal 1961-1990.

\begin{tabular}{|c|c|c|c|c|c|c|c|}
\hline Country & $\begin{array}{l}\text { Population } \\
\text { in } 2000 \\
\text { [thousand] }\end{array}$ & $\begin{array}{l}\text { Internally } \\
\text { renewable } \\
\text { water } \\
\text { resources } \\
\text { A } \\
{[\mathrm{mm} / \mathrm{yr}]}\end{array}$ & $\begin{array}{l}\text { Dev. } \\
(+/-) \\
{[\%]}\end{array}$ & $\begin{array}{l}\text { Internally } \\
\text { renewable } \\
\text { groundwater } \\
\text { resources } \\
\text { B } \\
{[\mathrm{mm} / \mathrm{yr}]}\end{array}$ & $\begin{array}{l}\text { Dev. } \\
(+/-) \\
{[\%]}\end{array}$ & $\begin{array}{l}\mathrm{B} / \mathrm{A} \\
{[\%]}\end{array}$ & $\begin{array}{l}\text { Per-capita internally } \\
\text { renewable ground- } \\
\text { water resources } \\
{\left[\mathrm{m}^{3} /(\text { capita yr) }]\right.}\end{array}$ \\
\hline Afghanistan & 21765 & 89.7 & 19.2 & 10.0 & 13.3 & 11.1 & 294 \\
\hline Algeria & 30291 & 15.8 & 31.3 & 2.6 & 19.9 & 16.7 & 201 \\
\hline Angola & 13134 & 176.4 & 4.5 & 104.7 & 6.4 & 59.4 & 9687 \\
\hline Argentina & 37032 & 125.2 & 12.8 & 53.2 & 6.9 & 42.5 & 3754 \\
\hline Armenia & 3787 & 97.7 & 20.8 & 25.7 & 18.5 & 26.3 & 192 \\
\hline Australia & 19138 & 100.6 & 2.7 & 34.1 & 0.5 & 33.9 & 13514 \\
\hline Austria & 8080 & 632.3 & 1.7 & 163.4 & 0.5 & 25.8 & 1660 \\
\hline Belarus & 10187 & 142.1 & 4.5 & 95.1 & 3.6 & 66.9 & 1795 \\
\hline Belgium & 10249 & 394.6 & 2.7 & 275.2 & 1.7 & 69.7 & 817 \\
\hline Belize & 226 & 759.6 & 4.8 & 327.0 & 2.3 & 43.0 & 31314 \\
\hline Benin & 6272 & 131.3 & 3.0 & 86.3 & 2.2 & 65.7 & 1558 \\
\hline Bhutan & 2085 & 597.5 & 11.1 & 76.6 & 8.4 & 12.8 & 1328 \\
\hline Bolivia & 8329 & 327.1 & 3.5 & 146.0 & 0.9 & 44.6 & 18071 \\
\hline Bosnia and Herzegovina & 3977 & 602.9 & 3.0 & 226.3 & 3.8 & 37.5 & 2906 \\
\hline Botswana & 1541 & -13.5 & 24.5 & 18.5 & 3.5 & -137.2 & 6655 \\
\hline Brazil & 170406 & 631.0 & 1.6 & 325.8 & 0.9 & 51.6 & 14610 \\
\hline Bulgaria & 7949 & 197.5 & 9.4 & 76.7 & 7.4 & 38.8 & 1055 \\
\hline Burkina Faso & 11535 & 49.2 & 0.6 & 38.9 & 1.5 & 79.0 & 902 \\
\hline China & 1275133 & 241.1 & 1.5 & 68.8 & 0.2 & 28.5 & 490 \\
\hline Colombia & 42105 & 1606.4 & 4.4 & 445.5 & 1.5 & 27.7 & 11307 \\
\hline Congo (DRC) & 50948 & 408.6 & 1.3 & 247.1 & 2.8 & 60.5 & 10446 \\
\hline Congo (RC) & 3018 & 488.9 & 1.9 & 349.0 & 1.9 & 71.4 & 29713 \\
\hline Costa Rica & 4024 & 1708.9 & 8.0 & 353.4 & 0.2 & 20.7 & 4081 \\
\hline Cote d'Ivoire & 16013 & 286.1 & 2.9 & 136.4 & 4.1 & 47.7 & 2706 \\
\hline Croatia & 4654 & 517.2 & 6.2 & 239.5 & 0.7 & 46.3 & 2843 \\
\hline Cuba & 11199 & 288.3 & 9.9 & 111.0 & 5.6 & 38.5 & 1062 \\
\hline Czech Republic & 10272 & 208.8 & 0.3 & 92.1 & 0.1 & 44.1 & 692 \\
\hline Denmark & 5320 & 487.9 & 2.6 & 362.5 & 1.6 & 74.3 & 2797 \\
\hline Djibouti & 632 & 36.2 & 42.7 & 3.3 & 36.3 & 9.1 & 109 \\
\hline Dominican Republic & 8373 & 361.2 & 16.6 & 120.2 & 9.2 & 33.3 & 691 \\
\hline Ecuador & 12646 & 1444.1 & 12.3 & 296.8 & 4.2 & 20.6 & 5565 \\
\hline Egypt & 67884 & -9.1 & 44.1 & 0.6 & 8.6 & -6.1 & 8 \\
\hline El Salvador & 6278 & 610.8 & 8.3 & 229.8 & 8.9 & 37.6 & 739 \\
\hline Equatorial Guinea & 457 & 1189.0 & 5.6 & 394.2 & 1.3 & 33.2 & 23318 \\
\hline Eritrea & 3659 & 61.6 & 7.4 & 5.9 & 16.4 & 9.5 & 193 \\
\hline Estonia & 1393 & 275.7 & 1.8 & 172.4 & 1.4 & 62.5 & 5345 \\
\hline Ethiopia & 62908 & 135.8 & 4.0 & 39.1 & 1.6 & 28.8 & 690 \\
\hline Falkland Islands & 2 & 370.0 & 3.2 & 225.6 & 0.2 & 61.0 & 1104476 \\
\hline Fiji & 814 & 1162.5 & 10.0 & 288.6 & 7.8 & 24.8 & 6368 \\
\hline
\end{tabular}


Table B1. Continued.

\begin{tabular}{|c|c|c|c|c|c|c|c|}
\hline Country & $\begin{array}{l}\text { Population } \\
\text { in } 2000 \\
\text { [thousand] }\end{array}$ & $\begin{array}{l}\text { Internally } \\
\text { renewable } \\
\text { water } \\
\text { resources } \\
\text { A } \\
{[\mathrm{mm} / \mathrm{yr}]}\end{array}$ & $\begin{array}{l}\text { Dev. } \\
(+/-) \\
{[\%]}\end{array}$ & $\begin{array}{l}\text { Internally } \\
\text { renewable } \\
\text { groundwater } \\
\text { resources } \\
\text { B } \\
{[\mathrm{mm} / \mathrm{yr}]}\end{array}$ & $\begin{array}{l}\text { Dev. } \\
(+/-) \\
{[\%]}\end{array}$ & $\begin{array}{l}\text { B/A } \\
{[\%]}\end{array}$ & $\begin{array}{l}\text { Per-capita internally } \\
\text { renewable ground- } \\
\text { water resources } \\
{\left[\mathrm{m}^{3} /(\text { capita yr })\right]}\end{array}$ \\
\hline Georgia & 5262 & 577.4 & 4.5 & 136.6 & 2.5 & 23.7 & 1795 \\
\hline Germany & 82017 & 315.6 & 1.5 & 200.7 & 0.3 & 63.6 & 861 \\
\hline Ghana & 19306 & 143.4 & 3.0 & 105.2 & 2.4 & 73.4 & 1232 \\
\hline Greece & 10610 & 313.5 & 1.3 & 90.5 & 0.4 & 28.9 & 1098 \\
\hline Greenland & 56 & 144.4 & 17.9 & 6.5 & 12.6 & 4.5 & 239740 \\
\hline Guatemala & 11385 & 1125.0 & 16.8 & 295.8 & 9.5 & 26.3 & 2794 \\
\hline Guinea & 8154 & 634.7 & 3.8 & 212.2 & 0.6 & 33.4 & 6317 \\
\hline Guinea-Bissau & 1199 & 563.5 & 5.0 & 204.6 & 2.7 & 36.3 & 5411 \\
\hline Guyana & 761 & 863.4 & 11.6 & 364.9 & 4.0 & 42.3 & 91912 \\
\hline Haiti & 8142 & 361.1 & 49.2 & 99.5 & 34.8 & 27.6 & 326 \\
\hline Honduras & 6417 & 730.2 & 5.9 & 231.7 & 5.6 & 31.7 & 3881 \\
\hline Hungary & 9968 & 107.2 & 4.6 & 72.9 & 4.3 & 68.0 & 668 \\
\hline Iceland & 279 & 1191.5 & 4.1 & 306.3 & 2.9 & 25.7 & 106189 \\
\hline India & 1008937 & 455.1 & 10.7 & 93.1 & 0.9 & 20.5 & 273 \\
\hline Indonesia & 212092 & 1240.8 & 3.6 & 441.8 & 4.0 & 35.6 & 3719 \\
\hline Iran & 70330 & 48.8 & 9.4 & 15.1 & 5.5 & 31.0 & 331 \\
\hline Iraq & 22946 & 13.2 & 113.3 & 17.9 & 10.1 & 135.8 & 327 \\
\hline Ireland & 3803 & 770.3 & 0.3 & 372.5 & 0.3 & 48.4 & 6603 \\
\hline Israel & 6040 & 139.2 & 17.7 & 41.9 & 10.4 & 30.1 & 141 \\
\hline Italy & 57530 & 448.2 & 1.9 & 147.3 & 0.7 & 32.9 & 757 \\
\hline Jamaica & 2576 & 603.7 & 51.3 & 136.8 & 33.2 & 22.7 & 588 \\
\hline Japan & 127096 & 990.4 & 4.2 & 278.7 & 2.3 & 28.1 & 798 \\
\hline Jordan & 4913 & 35.9 & 44.5 & 12.2 & 12.5 & 34.0 & 215 \\
\hline Kazakhstan & 16172 & 33.6 & 2.8 & 10.4 & 1.5 & 30.8 & 1679 \\
\hline Kenya & 30669 & 85.1 & 9.8 & 46.0 & 5.8 & 54.1 & 822 \\
\hline Korea (Dem. People's Rep.) & 22268 & 448.5 & 0.8 & 99.2 & 4.4 & 22.1 & 538 \\
\hline Korea (Republic of) & 46740 & 540.1 & 3.8 & 127.3 & 4.2 & 23.6 & 262 \\
\hline Kuwait & 1914 & 29.7 & 12.0 & 1.2 & 54.1 & 4.1 & 11 \\
\hline Kyrgyzstan & 4921 & 105.8 & 9.3 & 11.2 & 10.4 & 10.6 & 433 \\
\hline Laos & 5279 & 853.6 & 3.1 & 236.2 & 6.0 & 27.7 & 10071 \\
\hline Latvia & 2421 & 274.3 & 0.6 & 159.1 & 0.4 & 58.0 & 4137 \\
\hline Lebanon & 3496 & 370.0 & 4.7 & 100.4 & 2.4 & 27.1 & 292 \\
\hline Lesotho & 2035 & 129.0 & 0.5 & 15.6 & 0.1 & 12.1 & 231 \\
\hline Liberia & 2913 & 1557.7 & 1.4 & 419.3 & 1.8 & 26.9 & 13812 \\
\hline Libya & 5290 & 11.0 & 4.3 & 2.0 & 8.7 & 18.3 & 615 \\
\hline Lithuania & 3696 & 241.4 & 2.3 & 152.7 & 1.4 & 63.2 & 2628 \\
\hline Macedonia & 2034 & 245.9 & 0.9 & 61.6 & 1.1 & 25.1 & 758 \\
\hline Madagascar & 15970 & 588.8 & 2.0 & 216.1 & 2.9 & 36.7 & 7905 \\
\hline Malawi & 11308 & -24.3 & 16.8 & 163.9 & 0.8 & -675.8 & 1353 \\
\hline Malaysia & 22218 & 1312.9 & 3.6 & 480.8 & 2.5 & 36.6 & 6655 \\
\hline Mali & 11351 & 5.4 & 140.4 & 21.7 & 4.8 & 400.3 & 2294 \\
\hline Mauritania & 2665 & 8.0 & 71.5 & 3.6 & 4.1 & 44.7 & 1381 \\
\hline Mexico & 98872 & 193.4 & 0.1 & 50.5 & 0.6 & 26.1 & 989 \\
\hline Moldova & 4295 & 115.1 & 1.1 & 42.0 & 1.9 & 36.4 & 323 \\
\hline Mongolia & 2533 & 28.6 & 8.0 & 1.8 & 2.5 & 6.3 & 1079 \\
\hline Morocco & 29878 & 64.5 & 8.6 & 17.3 & 8.5 & 26.9 & 233 \\
\hline Mozambique & 18292 & 200.0 & 3.1 & 103.7 & 0.8 & 51.9 & 4207 \\
\hline Myanmar (Burma) & 47749 & 1200.0 & 4.3 & 225.5 & 3.8 & 18.8 & 3046 \\
\hline Namibia & 1757 & 15.2 & 5.3 & 10.3 & 1.0 & 68.0 & 4723 \\
\hline Nepal & 23043 & 1066.4 & 2.1 & 135.4 & 0.0 & 12.7 & 834 \\
\hline Netherlands & 15864 & 412.2 & 1.3 & 354.7 & 1.3 & 86.1 & 736 \\
\hline New Caledonia & 215 & 428.7 & 14.5 & 146.1 & 6.6 & 34.1 & 12430 \\
\hline New Zealand & 3778 & 1060.1 & 17.8 & 333.8 & 10.4 & 31.5 & 23022 \\
\hline Nicaragua & 5071 & 1171.8 & 3.3 & 336.6 & 0.7 & 28.7 & 7727 \\
\hline Niger & 10832 & 42.0 & 4.1 & 12.4 & 8.7 & 29.6 & 1332 \\
\hline
\end{tabular}


Table B1. Continued.

\begin{tabular}{|c|c|c|c|c|c|c|c|}
\hline Country & $\begin{array}{l}\text { Population } \\
\text { in } 2000 \\
\text { [thousand] }\end{array}$ & $\begin{array}{l}\text { Internally } \\
\text { renewable } \\
\text { water } \\
\text { resources } \\
\text { A } \\
{[\mathrm{mm} / \mathrm{yr}]}\end{array}$ & $\begin{array}{l}\text { Dev. } \\
(+/-) \\
{[\%]}\end{array}$ & $\begin{array}{l}\text { Internally } \\
\text { renewable } \\
\text { groundwater } \\
\text { resources } \\
\text { B } \\
{[\mathrm{mm} / \mathrm{yr}]}\end{array}$ & $\begin{array}{l}\text { Dev. } \\
(+/-) \\
{[\%]}\end{array}$ & $\begin{array}{l}\mathrm{B} / \mathrm{A} \\
{[\%]}\end{array}$ & $\begin{array}{l}\text { Per-capita internally } \\
\text { renewable ground- } \\
\text { water resources } \\
{\left[\mathrm{m}^{3} /(\text { capita yr)] }\right.}\end{array}$ \\
\hline Nigeria & 113862 & 304.5 & 0.3 & 163.1 & 1.3 & 53.6 & 1200 \\
\hline Norway & 4469 & 946.4 & 2.4 & 215.2 & 1.9 & 22.7 & 14738 \\
\hline Oman & 2538 & 43.1 & 11.0 & 2.6 & 38.8 & 5.9 & 309 \\
\hline Pakistan & 141256 & 62.2 & 15.5 & 12.2 & 13.3 & 19.5 & 74 \\
\hline Panama & 2856 & 1099.7 & 5.7 & 324.6 & 1.9 & 29.5 & 8249 \\
\hline Papua New Guinea & 4809 & 1577.9 & 0.0 & 457.7 & 0.1 & 29.0 & 34665 \\
\hline Paraguay & 5496 & 178.6 & 0.8 & 113.4 & 3.1 & 63.5 & 6427 \\
\hline Peru & 25662 & 1007.2 & 4.3 & 279.9 & 0.4 & 27.8 & 12674 \\
\hline Philippines & 75653 & 991.2 & 2.3 & 263.3 & 4.8 & 26.6 & 998 \\
\hline Poland & 38605 & 198.3 & 0.1 & 143.7 & 0.2 & 72.4 & 1133 \\
\hline Portugal & 10016 & 451.5 & 5.7 & 141.6 & 1.6 & 31.4 & 1249 \\
\hline Qatar & 565 & 8.3 & 35.3 & 1.3 & 62.6 & 15.2 & 24 \\
\hline Romania & 22438 & 215.0 & 1.7 & 93.4 & 0.7 & 43.4 & 973 \\
\hline Russia & 145491 & 210.1 & 1.1 & 54.1 & 0.6 & 25.8 & 5693 \\
\hline Rwanda & 7609 & 175.5 & 4.1 & 67.6 & 5.9 & 38.5 & 195 \\
\hline Saudi Arabia & 20346 & 12.8 & 70.2 & 0.9 & 66.1 & 7.4 & 90 \\
\hline Senegal & 9421 & 44.4 & 34.1 & 63.3 & 10.5 & 142.7 & 1257 \\
\hline Serbia and Montenegro & 10552 & 306.3 & 10.7 & 118.1 & 6.9 & 38.6 & 1131 \\
\hline Sierra Leone & 4405 & 1412.5 & 4.1 & 394.0 & 2.2 & 27.9 & 6150 \\
\hline Slovakia & 5399 & 247.1 & 3.6 & 115.6 & 3.5 & 46.8 & 1040 \\
\hline Slovenia & 1988 & 693.1 & 3.2 & 271.6 & 0.3 & 39.2 & 2777 \\
\hline Solomon Islands & 447 & 1406.5 & 3.5 & 419.0 & 11.9 & 29.8 & 23284 \\
\hline Somalia & 8778 & 20.1 & 36.3 & 9.5 & 5.7 & 47.5 & 678 \\
\hline South Africa & 43309 & 48.4 & 0.8 & 14.3 & 1.0 & 29.4 & 397 \\
\hline Spain & 39910 & 229.3 & 0.5 & 69.9 & 0.5 & 30.5 & 875 \\
\hline Sri Lanka & 18924 & 602.2 & 8.3 & 165.2 & 0.7 & 27.4 & 550 \\
\hline Sudan & 31095 & 11.9 & 2.6 & 21.9 & 2.6 & 184.1 & 1708 \\
\hline Suriname & 417 & 712.2 & 4.5 & 289.9 & 0.9 & 40.7 & 87753 \\
\hline Svalbard & 3 & 613.5 & 23.6 & 7.1 & 21.4 & 1.2 & 90166 \\
\hline Swaziland & 925 & 167.5 & 4.8 & 37.6 & 0.7 & 22.5 & 691 \\
\hline Sweden & 8842 & 401.2 & 0.4 & 142.4 & 0.8 & 35.5 & 6284 \\
\hline Switzerland & 7170 & 1069.8 & 8.9 & 228.1 & 2.6 & 21.3 & 1265 \\
\hline Syria & 16189 & 58.0 & 4.2 & 31.4 & 1.6 & 54.1 & 361 \\
\hline Tajikistan & 6087 & 261.3 & 8.7 & 34.6 & 6.8 & 13.3 & 800 \\
\hline Tanzania & 35119 & 136.7 & 3.4 & 93.1 & 4.1 & 68.1 & 2216 \\
\hline Thailand & 62806 & 389.6 & 0.5 & 178.4 & 2.2 & 45.8 & 1370 \\
\hline Timor Leste & 737 & 258.7 & 14.9 & 92.8 & 21.2 & 35.9 & 1898 \\
\hline Togo & 4527 & 193.4 & 1.4 & 130.8 & 2.5 & 67.6 & 1593 \\
\hline Tunisia & 9459 & 51.7 & 11.2 & 18.3 & 2.7 & 35.3 & 282 \\
\hline Turkey & 66668 & 235.6 & 4.1 & 56.3 & 2.5 & 23.9 & 643 \\
\hline Turkmenistan & 4737 & 14.3 & 4.8 & 1.7 & 14.3 & 11.6 & 170 \\
\hline Uganda & 23300 & 13.3 & 104.1 & 94.7 & 5.7 & 712.9 & 750 \\
\hline Ukraine & 49568 & 117.6 & 0.4 & 50.2 & 0.0 & 42.7 & 579 \\
\hline United Arab Emirates & 2606 & 11.9 & 20.9 & 3.0 & 18.3 & 25.4 & 77 \\
\hline United Kingdom & 59415 & 743.2 & 15.0 & 339.1 & 8.8 & 45.6 & 1316 \\
\hline Uruguay & 3337 & 513.0 & 1.7 & 175.3 & 1.4 & 34.2 & 9109 \\
\hline USA & 283230 & 252.7 & 3.0 & 88.3 & 0.7 & 35.0 & 2512 \\
\hline Uzbekistan & 24881 & 30.5 & 2.7 & 7.8 & 1.4 & 25.6 & 130 \\
\hline Vanuatu & 197 & 1258.0 & 0.1 & 358.8 & 5.5 & 28.5 & 21602 \\
\hline Venezuela & 24170 & 845.9 & 0.3 & 281.8 & 0.8 & 33.3 & 9396 \\
\hline Vietnam & 78137 & 727.1 & 4.9 & 186.1 & 1.6 & 25.6 & 678 \\
\hline Western Sahara & 223 & 7.9 & 50.4 & 0.4 & 79.6 & 5.7 & 536 \\
\hline Yemen & 18349 & 36.7 & 22.1 & 2.6 & 11.8 & 7.1 & 65 \\
\hline Zambia & 10421 & 94.7 & 3.3 & 108.4 & 0.9 & 114.4 & 7051 \\
\hline Zimbabwe & 12627 & 80.2 & 0.4 & 31.9 & 0.1 & 39.8 & 976 \\
\hline
\end{tabular}


Acknowledgements. The authors are grateful for the contribution of M. Edmunds, University of Oxford, who compiled the estimates of local groundwater recharge in semi-arid and arid regions around the world. They thank M. Flörke, University of Kassel, for her input with respect to model modification in semi-arid and arid region, and K. Verzano, University of Kassel, and M. Hunger, Frankfurt University, for their programming work. Part of the research presented in this publication was funded by the International Atomic Energy Agency (IAEA), Vienna.

Edited by: K. Bishop

\section{References}

Adam, J. C. and Lettenmeier, D. P.: Adjustment of global gridded precipitation for systematic bias, J. Geophys. Res.-Atmos., 108(D9), 4257, doi:10.1029/2002JD002499, 2003.

Alcamo, J., Döll, P., Henrichs, T., Kaspar, F., Lehner, B., Rösch, T., and Siebert, S.: Development and testing of the WaterGAP 2 global model of water use and availability, Hydrol. Sci., 48, 317-337, 2003.

Brown, J., Ferrians Jr., O. J., Heginbottom, J. A., and Melnikov, E. S.: Digital Circum-Arctic Map of Permafrost and Ground-Ice Conditions, International Permafrost Association Data and Information Working Group, Circumpolar Active-Layer Permafrost System (CAPS), CD-ROM version 1.0. National Snow and Ice Data Center, University of Colorado, Boulder, 1998.

Bullock, A., Andrew, A., and Mngodo, R.: Regional surface water resources and drought assessment, in: UNESCO Tech. Doc. in Hydrol. No. 15, Southern African FRIEND, Paris, 40-93, 1997.

Canadian Geological Survey: Generalized Geological Map of the World and Linked Databases, Open File Report 2915d, CDROM, 1995.

CIESIN (Center for International Earth Science Information Network): Gridded Population of the World Version 3 (GPWv3): Population Grids, Palisades, NY: Socioeconomic Data and Applications Center (SEDAC), Columbia University, http://sedac. ciesin.columbia.edu/gpw, 2005.

Dirmeyer, P. A., Gao, X.., Zhao, M., Guo, Y., Oki, T., and Hanasaki, N.: The Second Global Soil Wetness Project (GSWP-2): MultiModel Analysis and Implications for our Perception of the Land Surface, COLA Technical Report, ftp://grads.iges.org/pub/ctr/ ctr_185.pdf, 2005.

Döll, P. and Flörke, M.: Global-Scale Estimation of Diffuse Groundwater Recharge, Frankfurt Hydrology Paper 03, Institute of Physical Geography, Frankfurt University, Frankfurt am Main, 2005.

Döll, P., Kaspar, F., and Lehner, B.: A global hydrological model for deriving water availability indicators: model tuning and validation, J. Hydrol., 270, 105-134, 2003.

Döll, P. and Lehner, B.: Validation of a new global 30-min drainage direction map, J. Hydrol., 258, 214-231, 2002.

Döll, P. and Siebert, S.: Global modeling of irrigation water requirements, Water Resour. Res., 38, 8.1-8.10, doi:10.1029/2001WR000355, 2002.

Döll, P., Lehner, B., and Kaspar, F.: Global modeling of groundwater recharge, in: Proceedings of Third International Conference on Water Resources and the Environment Research, edited by:
Schmitz, G. H., Technical University of Dresden, Germany, I, 27-31, 2002.

ESRI (Environmental Systems Research Institute): Data and Maps 2004, 2004.

FAO (Food and Agriculture Organization of the United Nations): Digital Soil Map of the World and Derived Soil Properties, CDROM version 3.5, 1995.

FAO (Food and Agriculture Organization of the United Nations): Review of world water resources by country, FAO Water Report No. 23, Rome, 2003.

FAO (Food and Agriculture Organization of the United Nations), Land and Water Development Division: AQUASTAT online database, including water resources per country, http://www.fao. org/nr/water/aquastat/dbase/index.stm, 2005.

Feick, S., Siebert, S., and Döll, P.: A Digital Global Map of Artificially Drained Agricultural Areas, Frankfurt Hydrology Paper 04, Institute of Physical Geography, Frankfurt University, Frankfurt am Main, http://www.geo.uni-frankfurt.de/ipg/ag/dl/ publikationen/index.html, 2005.

Fuchs, T., Schneider, U., and Rudolf, B.: Global precipitation analysis products of GPCC, GPCC/Deutscher Wetterdienst, http://www.dwd.de/en/FundE/Klima/KLIS/int/GPCC/ Reports_Publications/QR/GPCC_intro_products_2007.pdf, 2007.

Güntner, A., Stuck, J., Werth, S., Döll, P., Verzano, K., and Merz, B.: A global analysis of temporal and spatial variations in continental water storage, Water Resour. Res., 43, W05416, doi:10.1029/2006WR005247, 2007a.

Güntner, A., Schmidt, R., and Döll, P.: Supporting large-scale hydrogeological monitoring and modelling by time-variable gravity data, Hydrogeol. J., 15, 167-170, doi:10.1007/s10040-0060089-1, 2007b.

Guo, Z., Dirmeyer, P.A., Hu, Z.-Z., Gao, X., and Zhao, M.: Evaluation of the Second Global Soil Wetness Project soil moisture simulations: 2. Sensitivity to external meteorological forcing, J. Geophys. Res., 111, D22S03, doi:10.1029/2006JD007845, 2006.

Haberlandt, U., Klöcking, B., Krysanova, V., and Becker, A.: Regionalisation of the base flow index from dynamically simulated flow components - a case study in the Elbe River Basin, J. Hydrol., 248, 35-53, 2001.

Hevesi, J. A., Flint, A. L., and Flint, L. E.: Simulation of Net Infiltration and Potential Recharge Using a Distributed-Parameter Watershed Model of the Death Valley Region, Nevada and California, USGS Water-Resources Investigations Report 03-4090, Sacramento, 2003.

Hoelzle, M. and Haeberli, W.: World Glacier Inventory. World Glacier Monitoring Service, National Snow and Ice Data Center, University of Colorado, Boulder, 1999.

Hunger, M. and Döll, P.: Value of river discharge data for globalscale hydrological modeling, Hydrol. Earth Syst. Sci., 12, 841861,2008 , http://www.hydrol-earth-syst-sci.net/12/841/2008/.

Jankiewicz, P., Neumann, J., Duijnisveld, W. H. M., Wessolek, G., Wycisk, P., and Hennings, V.: Abflusshöhe, Sickerwasserrate, Grundwasserneubildung - Drei Themen im Hydrologischen Atlas von Deutschland, Hydrologie und Wasserbewirtschaftung, 49, 2-13, 2005.

Janssen, P. H. M. and Heuberger, P. S. C.: Calibration of processoriented models, Ecol. Model., 83, 55-66, 1995. 
Keese, K. E., Scanlon, B. R., and Reedy, R. C.: Assessing controls on diffuse groundwater recharge using unsaturated flow modeling, Water Resour. Res., 41, W06010, doi:10.1029/2004WR003481, 2005.

Lavapuro, M., Lipponen, A., and Artimo, A.: Groundwater sustainability indicators: testing with Finnish data, in: Groundwater resources sustainability indicators, edited by: Vrba, J. and Lipponen, A., IHP-VI Series on Groundwater No. 14, UNESCO, 52-72, 2007.

Legates, D. R.: A climatology of global precipitation, Publ. Climatol., 40(1), Center for Climatic Research, University of Delaware, 1987.

Lerner, D. N., Issar, A. S., and Simmers, I.: Groundwater recharge: a guide to understanding and estimating natural recharge, International Contributions to Hydrogeology, 8, Heise, Hannover, 1990.

L'vovich, M. I.: World Water Resources and their Future. American Geophysical Union, Washington D.C., 1979.

Margat, J.: Les Eaux Souterraines dans le Monde, BRGM R31780, Orleans, 1990.

Mitchell, T. D. and Jones, P. D.: An improved method of constructing a database of monthly climate observations and associated high-resolution grids, Int. J. Climatol., 25, 693-712, 2005.

Neumann, J.: Flächendifferenzierte Grundwasserneubildung von Deutschland - Entwicklung und Anwendung des makroskaligen Verfahrens HAD-GW Neu, Dissertation, Martin-LutherUniversität Halle-Wittenberg, ULB Sachsen-Anhalt, 137 pp., 2005.

New, M., Hulme, M., and Jones, P. D.: Representing twentieth century space-time climate variability, Part 1: development of a 1961-90 mean monthly terrestrial climatology, J. Climate, 12, 829-856, 1999.

New, M., Hulme, M., and Jones, P. D.: Representing twentieth century space-time climate variability, Part 2: development of 190196 monthly grids of terrestrial surface climate, J. Climate, 13, 2217-2238, 2000.

Scanlon, B. R., Keese, K. E., Flint, A. L., Flint, L. E., Gaye, C. B., Edmunds, W. M., and Simmers, I.: Global synthesis of groundwater recharge in semiarid and arid regions, Hydrol. Processes, 20, 3335-3370, 2006.
Scanlon, B. R., Healy, R. W., and Cook, P. G.: Choosing appropriate techniques for quantifying groundwater recharge, Hydrogeol. J., 10, 18-39, 2002.

Seguin, J. J.: Hydrogeological Map of Africa: a prototype at 1/10 M scale, Baureau des Recherches Géologiques et Minières (BGRM)/Service Eau, France, 2005.

Simmers, I.: Recharge of phreatic aquifers in (semi-)arid areas, A. A. Balkema, Rotterdam, 1997.

Small, E. E.: Climatic controls on diffuse groundwater recharge in semiarid environments of the southwestern United States, Water Resour. Res., 41, W04012, doi:10.1029/2004WR003193, 2005.

Tallaksen, L. M.: A review of baseflow recession analysis, J. Hydrol., 165, 349-370, 1995.

UNEP (United Nations Environment Programme): World Atlas of Desertification, 1992.

Vassolo, S. and Döll, P.: Global-scale gridded estimates of thermoelectric power and manufacturing water use, Water Resour. Res., 41, W04010, doi:10.1029/2004WR003360, 2005.

Vogel, J. C. and Van Urk, H.: Isotopic composition of groundwater in semi-arid regions of southern Africa, J. Hydrol., 25, 23-26, 1975.

WRI (World Resources Institute): EarthTrends Water Resources and Freshwater Ecosystems Data Tables, Freshwater Resources 2005, http://earthtrends.wri.org/pdf_library/data_tables/ wat2_2005.pdf, 2005a.

WRI (World Resources Institute): EarthTrends Water Resources and Freshwater Ecosystems Searchable Database, Internal Renewable Water Resources (IRWR): Groundwater recharge, volume, http://earthtrends.wri.org/searchable_db/index.php?theme= 2, 2005b.

WRI (World Resources Institute): World Resources 2000-2001 People and ecosystems: The fraying web of life, 2000.

WRI (World Resources Institute): EarthTrends Water Resources and Freshwater Ecosystems Data Tables, Groundwater and Desalinization 2000, http://earthtrends.wri.org/pdf_library/data_ tables/fw2n_2000.pdf, 2000. 